\title{
Archeological Testing at Prehistoric Site 41UR36 Upshur County, Texas
}

Steven Ahr

Follow this and additional works at: https://scholarworks.sfasu.edu/ita

Part of the American Material Culture Commons, Archaeological Anthropology Commons, Environmental Studies Commons, Other American Studies Commons, Other Arts and Humanities Commons, Other History of Art, Architecture, and Archaeology Commons, and the United States History Commons

Tell us how this article helped you.

This Article is brought to you for free and open access by the Center for Regional Heritage Research at SFA ScholarWorks. It has been accepted for inclusion in Index of Texas Archaeology: Open Access Gray Literature from the Lone Star State by an authorized editor of SFA ScholarWorks. For more information, please contact cdsscholarworks@sfasu.edu. 


\section{Archeological Testing at Prehistoric Site 41UR36 Upshur County, Texas}

\section{Licensing Statement}

This is a work produced for the Texas Department of Transportation (TxDOT) by the report producer. TxDOT and the report producer jointly own all rights, title, and interest in and to all intellectual property developed under TXDOT's contract with the report producer. The report may be cited and brief passages from this publication may be reproduced without permission provided that credit is given to both TxDOT and the report producer. Permission to reprint an entire chapter, section, figures or tables must be obtained in advance from either the Supervisor of the Archeological Studies Branch, Environmental Affairs Division, Texas Department of Transportation, 125 East 11th Street, Austin, Texas, 78701 or from the report producer. 


\section{TEXAS DEPARTMENT OF TRANSPORTATION ENVIRONMENTAL AFFAIRS DIVISION}

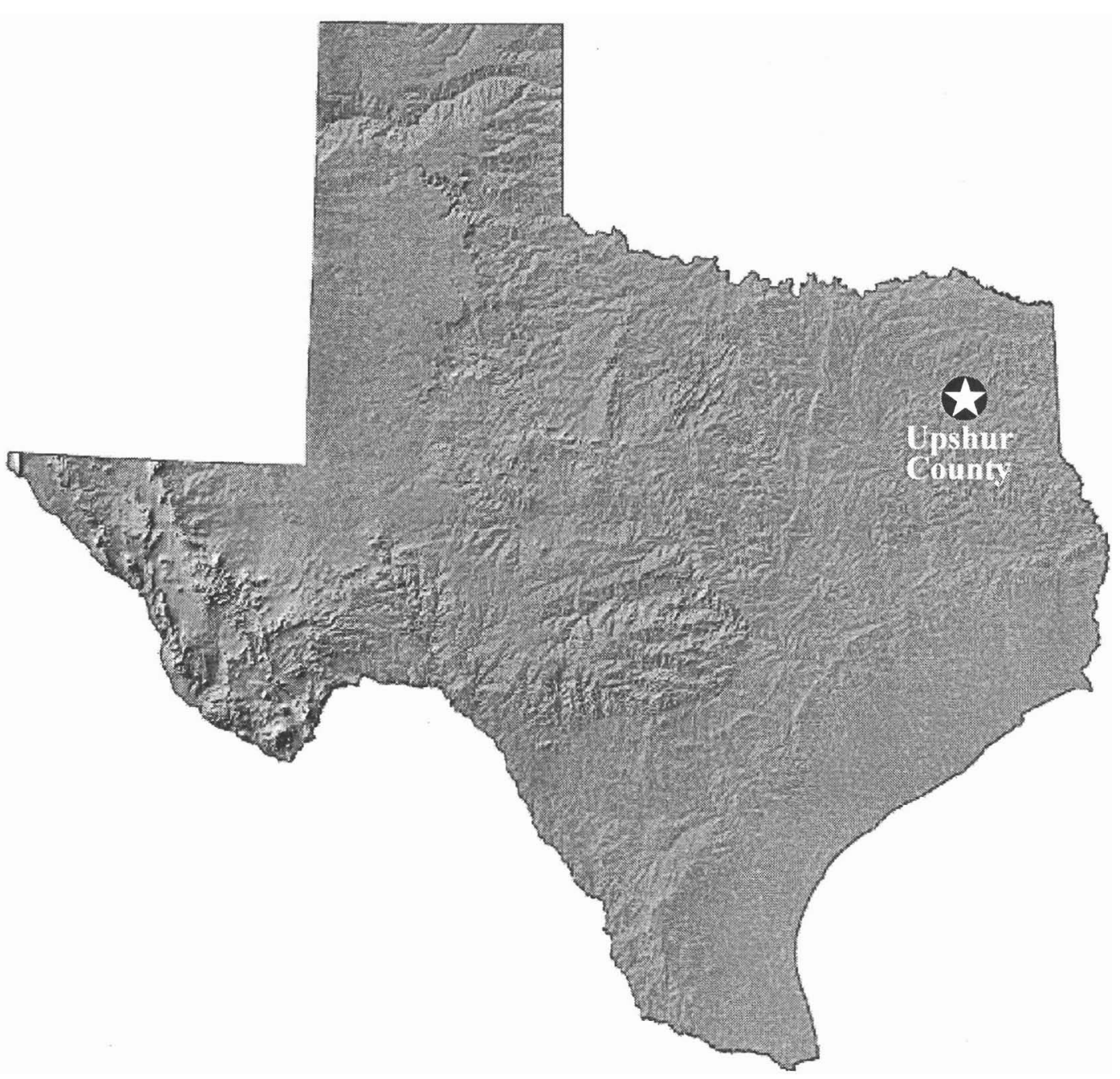

\section{ARCHEOLOGICAL TESTING at PREHISTORIC SITE 41UR36 UPSHUR COUNTY, TEXAS}

by Steven Ahr 


\title{
ARCHEOLOGICAL TESTING at PREHISTORICSITE 41UR36, UPSHUR COUNTY, TEXAS
}

Occasional Papers of the Archeological Studies Program

Volume 2, No. 1

\author{
Steven Ahr
}

Texas Department of Transportation

Environmental Affairs Division

Archeological Studies Program

Austin, Texas 


\section{ARCHEOLOGICAL TESTING at PREHISTORIC SITE 41 UR36, UPSHUR COUNTY, TEXAS}

Occasional Papers of the Archeological Studies Program

Volume 2, No. 1

Copyright 2002 by the Texas Department of Transportation (TxDOT)

All rightsreserved.

Published by the Texas Department of Transportation

January 2002 Austin, Texas

on acid-free paper

For further information on this and other TXDOT archeologicalpublications

please contact:

Texas Department of Transportation

Environmental Affairs Division

Archeological Studies Program

Nancy A. Kenmotsu, Ph.D., supervisor

Archeological Studies Program

A. McGraw, Series Editor

Production of this report was directed by

Timothy Meade 


\section{MANAGEMENT SUMMARY}

From September 27-30,1999, TxDOT archeologists conducted archeological testing of site 41UR36 within the proposed areas of impact for the FM 1002 widening at Glade Creek in Upshur County. Archeologists hand-excavated four $1-\mathrm{x}-1-\mathrm{m}$ test units and one $1.5-\mathrm{x}-0.5-\mathrm{m}$ test unit. The goal was to assess the integrity of the portion of the site within the A rea of Potential Effect (APE) and determine whether it was eligible for listing on the National Register of Historic Places.

Relatively few temporally or functionally diagnostic tools were recovered. Except for two Middle Archaic and one Late Archaic Period projectile points, only one other formal tool, a large axe-like biface, was recovered. The remainder consists of a few culturally modified stones and an expedient edge-modified flake. The twelve ceramic sherds recovered from the site are comprised of body sherds and one rim sherd, that fit within the descriptive range of ceramics identified at this site in 1985 during the Big Sandy Project (e.g., Late Caddoan Period brushed, incised, and punctated ceramic wares). The three identified features consisted of only a few disarticulated rocks. No bone, shell, charred materials, or discolored sediments were observed in association with any of the features. Furthermore, none of the surrounding matrix could be distinguished from the feature matrix on sedimentologic or pedologic properties.

Testing results indicate that some of thearcheological deposits at 41U R36 may be stratified. An isolated, discrete Archaic occupation zone appears to be present below the range of mixed deposits. However, the portion of the site within the area APE does not offer reasonable potential to contain information to address significant research issues about land use, subsistence, technology, chronology, or site function. Finally, features and presumed associated artifacts are only tenuously linked and without sufficient temporal controls, stronger relationships cannot be firmly established.

Based on these investigationsthe portion of site 41UR36 within the proposed widening will not likely yield information that would contribute to the NRHP eligibility of thesite. Therefore, the proposed project should have no effect on archeological historic properties and no further archeological work is recommended for the proposed bridge widening. 



\section{TABLEOF CONTENTS}

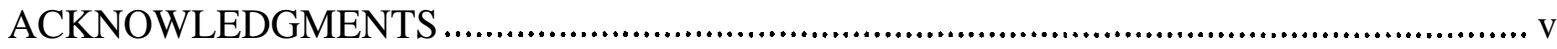

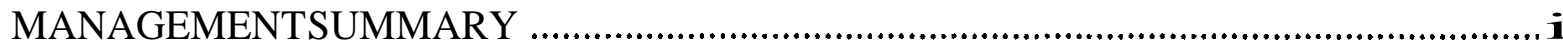

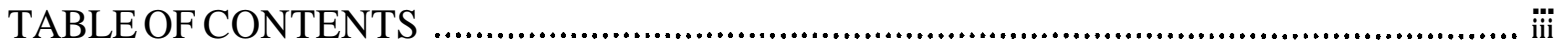

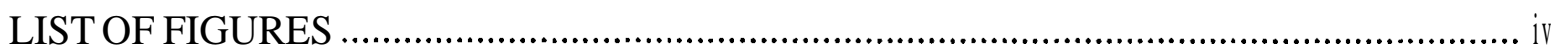

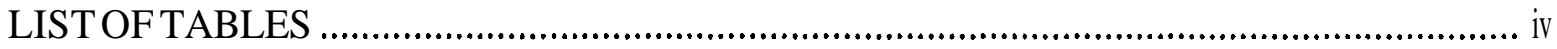

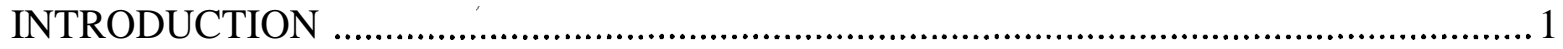

ENVIRONMENTALBACKGROUND .................................................................... 1

CULTURALAND ARCHEOLOGICAL BACKGROUND ...........................................

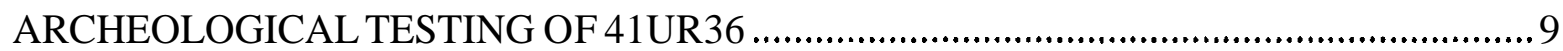

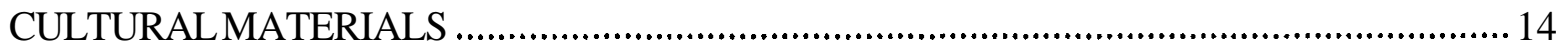

CONCLUSIONS AND RECOMMENDATIONS ….................................................... 23

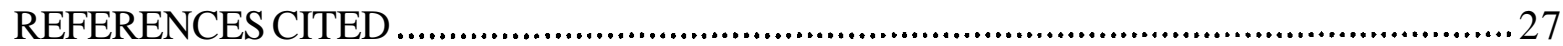

APPENDIX TEST UNIT PROFILES AND BACKHOE TRENCH DESCRIPTIONS .........31 


\section{LIST OF FIGURES}

Figure 1. Project area location on Upshur County Map. ........................................................... 2

Figure 2. Project area overview. looking north...................................................................

Figure 3. Schematic cross-section of Glade Creek Valley........................................................5

Figure 4. Shovel tests and backhoe trenches from TxDOT and PAI survey. .............................. 10

Figure 5. Backhoe trenchesand test units from TxDOT archeological testing..........................12

Figure 6. West view of Backhoe Trench 1b and Test Unit 1................................................. 13

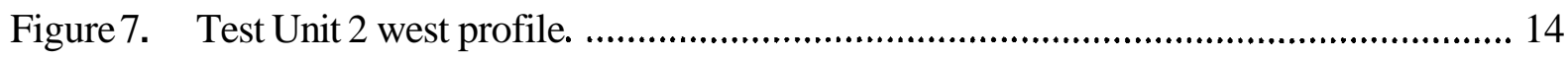

Figure 8. West view of Backhoe Trench 3b. Test Unit 3. and Feature 2. .................................. 15

Figure 9. View of Feature 2 in Backhoe Trench 3b................................................................ 16

Figure 10. View of Feature 3 in Test Unit 3 ..................................................................17

Figure 11 Selected ceramic sherds from 41UR36: (a) incised. TU 1. LV 3;

(b) brushed. TU 1. LV 3; (c) brushed. TU 2, LV 5 ............................................. 20

Figure 12. Bifacially flaked tools fiom 41UR36: (a) biface. TU 1,LV 9;

(b) Ellis-like dartpoint. TU 1. LV 7; (c) Gary dartpoint. TU 2. LV 11;

(d) Yarbrough-like dartpoint base. TU 2. LV 13. ................................................... 20

Figure 13. Groundstone and edge-modified tools fiom 41UR36:(a) hematite stone.

TU 4. LV 9; (b) abrader stone. TU 3, LV 9; (c) incised rock. TU 4. LV 9;

(d) edge modified flake. TU 3, LV 4, .................................................................... 21

Figure 14. Debitage densities in test units at 41UR36..........................................................23

Figure 15. Site-wide debitagedensity by level. ....................................................................... 24

\section{LIST OFTABLES}

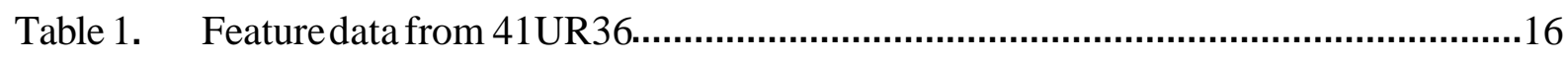

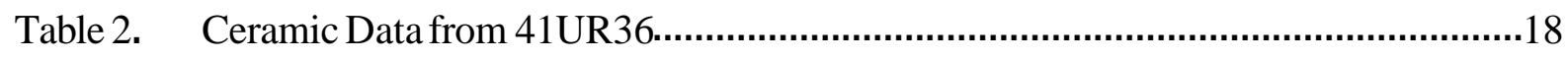

Table 3. Lithic tool data from 41UR36 ……………................................................... 19 


\section{ACKNOWLEDGMENTS}

Several individualscontributed to this project. Bobby Jones, John Callison, and Franklin Allen from the Atlanta District of the Texas Department of Transportation coordinated this project at the local level. They also participated in the fieldwork during survey and excavation, and negotiatedour fieldwork needs with our gracious landowner,Ms. Fitzgerald. The Linden maintenanceoffice providedequipment support, and Johnny Haskins from offi c eserved as backhoe operator. Jay Tullos from the TxDOT Tyler Districtalso provided valuable field assistance. THC ArcheologicalStewards Mark Walters and Patti Haskins visited the excavation site and provided valuable insights. Additionally, Tim Perttula shared his knowledge and expertise about the site.

From the EnvironmentalAffairs Division(ENV) at TxDOT, Diane Dismukes helped during the initial reconnaissance of thisproject.Lain Ellis and Jesus Gonzales from ENV provided much labor and field expertise during the excavations. Mr. Gonzales also helped out in the laboratory processing of the recovered artifacts, and Dennis Price provided assistance in the ceramic analysis. Nancy Kenmotsu, Archeological Studies Branch Supervisor at ENV, provided guidance during the project and was particularly helpful during the ceramic analysis. She, Lain Ellis, and A I McGraw made valuablecomments on earlier drafts of this report. Gregg Quinn took the artifact photographs used in the report. To all these individuals, and any that may have been inadvertentlyomitted, I offer my sincere thanks. 



\section{INTRODUCTION}

The AtlantaDistrict of the Texas Department of Transportation(TxDOT) proposed the replacement of the bridge at Glade Creek, along FM 1002 in Upshur County (Figure 1 and 2). The limits for the project extend from $170 \mathrm{~m}$ south of the existing bridge to $195 \mathrm{~m}$ north of the bridge. The existing bridge will be replaced by a concrete structure that includes two 24-m spans for a total length of $48 \mathrm{~m}$. Within the construction easement, a temporary detour $360 \mathrm{~m}$ in length will be constructed across Glade Creek to the east of the existing bridge. The proposed rightof-way varies from the existing width of $24.4 \mathrm{~m}$ to a maximum of $50.5 \mathrm{~m}$. The total project area, including existing and proposed right-ofway, is less than 5 acres. Existing right-of-way consists of approximately 1.54 acres. Approximately 1.83 acres of additional right-of-way will be required for the new bridge, and approximately 1 acre will be needed for the construction easement.

On October 21,1998, TxDOT archeologists Steve Ahr and Dianne Dismukes conducted a reconnaissance of the project area to determine the amount of the site that would be impacted by the bridge widening. Five shovel tests were excavated in the APE. Due to the nature of the proposed impacts and the presence of previously recorded site 4 1UR36, additional archeological survey was recommended.

On March 29-31, 1999, archeologists from Prewitt and Associates, Inc. (PAI) performed an archeologicalsurvey to delineate the horizontal and vertical boundaries of the site within the project area. Buried archeological materials relating to 41 UR 36 were identified in backhoe trenches and shovel tests on the south side of Glade Creek. PA I concluded that the deposits were potentially stratified and intact with sufficient integrity to be eligible for inclusionon the NRHP and/ordesignation as a State Archeo- logical Landmark (SAL). Additional testing was recommended. In a letter to SHPO dated May 7,1999, TxDOT proposed that three 1$\mathrm{x}-1-\mathrm{m}$ test units be excavated on the east side of FM 1002, and one on the west side. Based on site size and distribution of identified cultural materials, it was determined that this level of testing should be sufficientto determine eligibility of the portion of thesite within the project limits. On May 12,1999, SHPO concurred with these recommendations.

From September 27-30,1999, archeological investigationswere conducted at the Site 41UR36. The purpose of these investigations was to assess the integrity of the portion of the site within the APE and determine whetheror not that portion could contribute to the site's eligibility for the NHRP. This report details those efforts.

\section{ENVIRONMENTALBACKGROUND}

\section{Site Setting}

Site 41UR36 is situated on the south side of Glade Creek upon a flat terrace at 360 feet above mean sea level (amsl) between the upland valley wall and the modem Glade Creek floodplain(Figure 3). The floodplainis $150 \mathrm{~m}$ wide, and is bounded by valley walls and upland terrace edges approximately $50 \mathrm{~m}$ to the south, and $100 \mathrm{~m}$ to the north. South from the edge of the terrace the site gradually slopes down to a small swale near the southern boundary of the the project. Southward from this swale, elevation rises gradually to about 370 feet amsl. North of the creek, the floodplain has a lower gradient, rising gradually to 350 feet amsl over a distance of approximately $300 \mathrm{~m}$. Several seasonally inundated wetlands are present north of the creek.

A majority of the recorded site area above the creek has been cleared of trees and is currently 
This Page Redacted Per THC Policy 
a fallow field on the east of FM 1002, with open pasture on the west side of FM 1002. Based on informationin Perttulaet al. (1986), site 41UR36 covers a large known area (ca. $7,500 \mathrm{~m}^{2}$ ), and likely extends well beyond project boundaries up- and down- stream.

\section{Climate and Hydrology}

Climate in project area is classified as humid mesothermal. Summers are long and hot, and winters are cool and short. Winter average temperature is about 46 degrees $\mathrm{F}$, while average summer temperatures are 81 degrees $F$ (Roberts 1983). High rainfall is typical, and annual precipitation ranges between 115-125 $\mathrm{cm}$, most of which occurs during the spring and fall (Perttula et al. 1986:5-6). Surface run off is directed by the gently undulating topography which is dissected by numerous small intermittent streams that drain into major drainage basins to the north and south of Upshur County.

Glade Creek is within the upper Sabine River basin, and flows about four kilometerssouthwest where it empties into Big Sandy Creek near the Wood County line. From there, Big Sandy Creek flows southeast and empties into the Sabine River. The Sabine River flows southeastward and empties into the Gulf of Mexico near Beaumont, Texas.

\section{Physiography, Geology, and Soils}

The project area is located within the Gulf Coastal Plain Physiographic Province (Fenneman 1931). The site is situated on the south side of Glade Creek on a flat bench between the upland valley wall and Glade Creek floodplain(Figure 4).

Bowie fine sandy loam (BoC) is mapped on the bench. This soil has developed on the finegrained, light gray to brownish gray Queen City Sand formation (Eqc), and is generallydeep and gently sloping. The upper six inches is comprised of brown, fine sandy loam, which overlies a pale brown fine sandy loam to about 12 inches. Subsoil (44-72 inches below surface) consists ofyellowish brown sandy clay loam with reddish and grayish mottles that increase with increasing depth (Roberts 1983:14). Ironstone pebbles are common throughout. Thickness of artifact bearing sands ranges from 100 to $140 \mathrm{~cm}$.

The active floodplain to the north of the site is comprised of luka fine sandy loam (lu). This deep soil is found on small floodplains in this area and consists largely of dark grayish brown sandy loam and fine sandy loam (Roberts 1983:19). These soils are frequently flooded.

The southern boundary of the site appears to be a small swale which marks the divide between the Queen City sands (Eqc) associated with the site and the upland valley wall sands that developed on the Sparta Sands (Es) and the Weches Formation (Ew) (Bureau of Economic Geology 1965). Ironstone concretions are common throughout these deposits. Lilbert loamy fine sand $(\mathrm{LbC})$ has formed on these uplands and consists of brown loamy fine sand, with yellowish brown sandy clay loam and reddish and brownish mottlesin the subsoil (Roberts 1983:24).

\section{Ecological Setting}

The site is located within the Pine Hardwood forest of Texas (Gould 1975). The

Pineywoods area is characterized by moderately dense woodland, such as Sweetgum, Sassafras, Red and White Oaks, and Loblolly Pine. Vegetation also includes various grasses such as smutgrass, broomsedge, bluestem, and red lovegrass(Gould 1975). The immediate project area is typified by east Texas forest overstory, with hardwood forests along drainages. The project area falls within the 


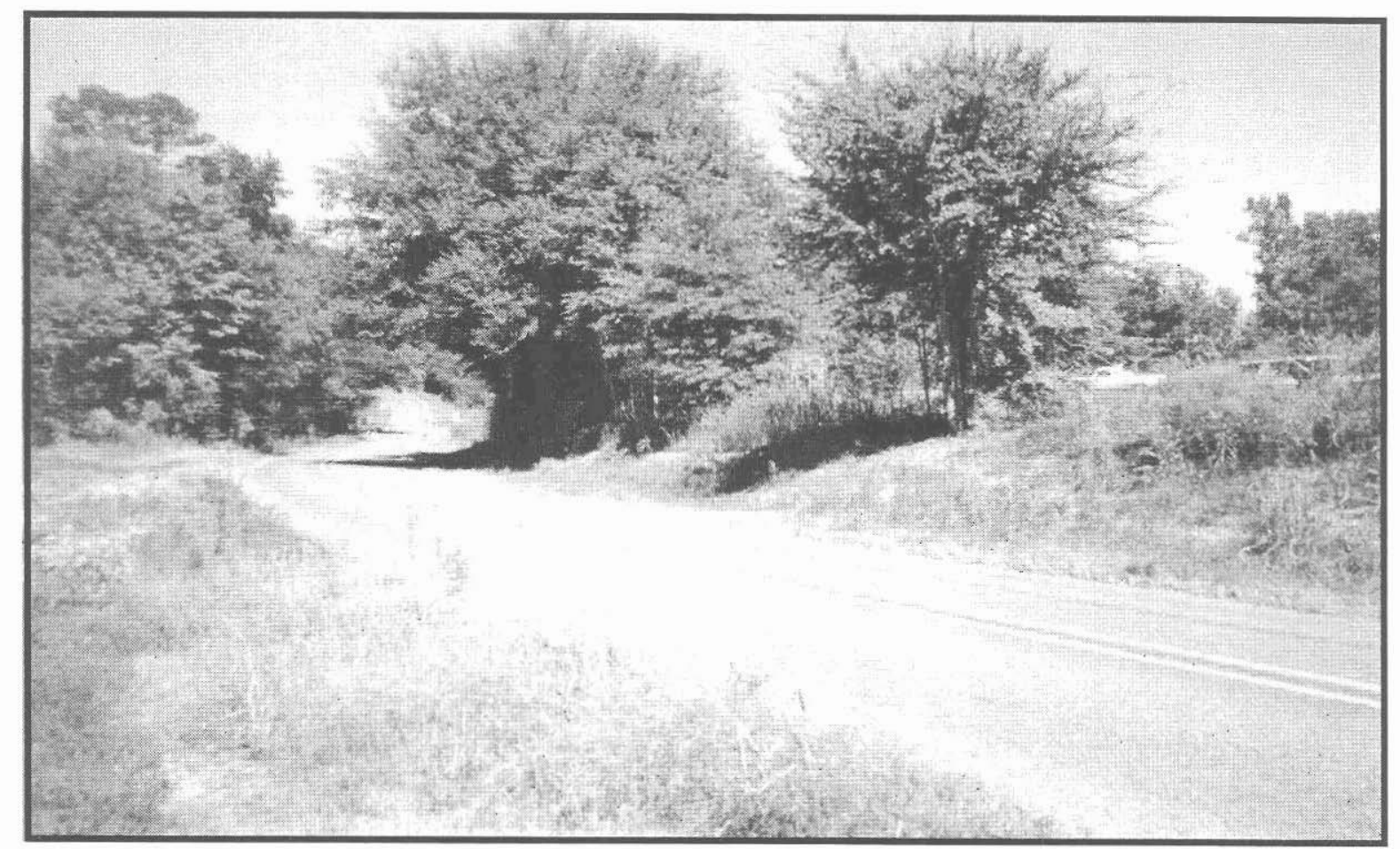

Figure 2. Project area overview, looking north.

Austroriparian biotic province as defined by Blair (1950). The diversity of this habitat would have provided an economically diverse variety ofmammals, reptiles, amphibian, and bird species. Probably the most notable and exploitablespecies would have been whitetailed deer.

\section{CULTURAL AND ARCHEOLOGICAL BACKGROUND}

\section{Cultural Background}

Previous work at 41UR36 indicates that both Archaic and Caddoancomponentsare present. The Archaic period in East Texas (7000 B.C. to 200 B.C.) is typified by a greater reliance on plant remains. Hardwood nut shells and burned rock concentrations at sites are common. During this period, huntergatherers are said to have reduced mobility and decreased in territory size. Many of these adaptations were likely due to population increases. Cemeteries are common, along with less reliance on exotic lithicmaterials and greater use of localized resources. Sites are located on a wide range of topographic and geomorphic settings, and are typically dominated by lithic assemblages. with larger accumulationsof refuse. Diagnosticartifacts include early style Gary dart points and Clear Fork tools (Fields et al. 1993; Perttula 1999: Perttula and K enmotsu 1993; Perttula etal. 1993; Story 1990).

The Archaic is typically divided into three periods: Early, Middle, and Late. The Early Archaic in East Texas in not well known. Most known sites are distributed on terrace and upland projections within majordrainage basins (Perttulaet al. 1986:50). These widely distributed sites tend to be heavy-use, time-compressed, and repeatedly used occupation areas. The Middle Archaic is relatively well known in East Texas, and in the upper Sabine Drainage Basin (see Perttula et al. 1986:50). A generalized hunting and gatheringeconomy prevailed, along with some form of exchange systems 


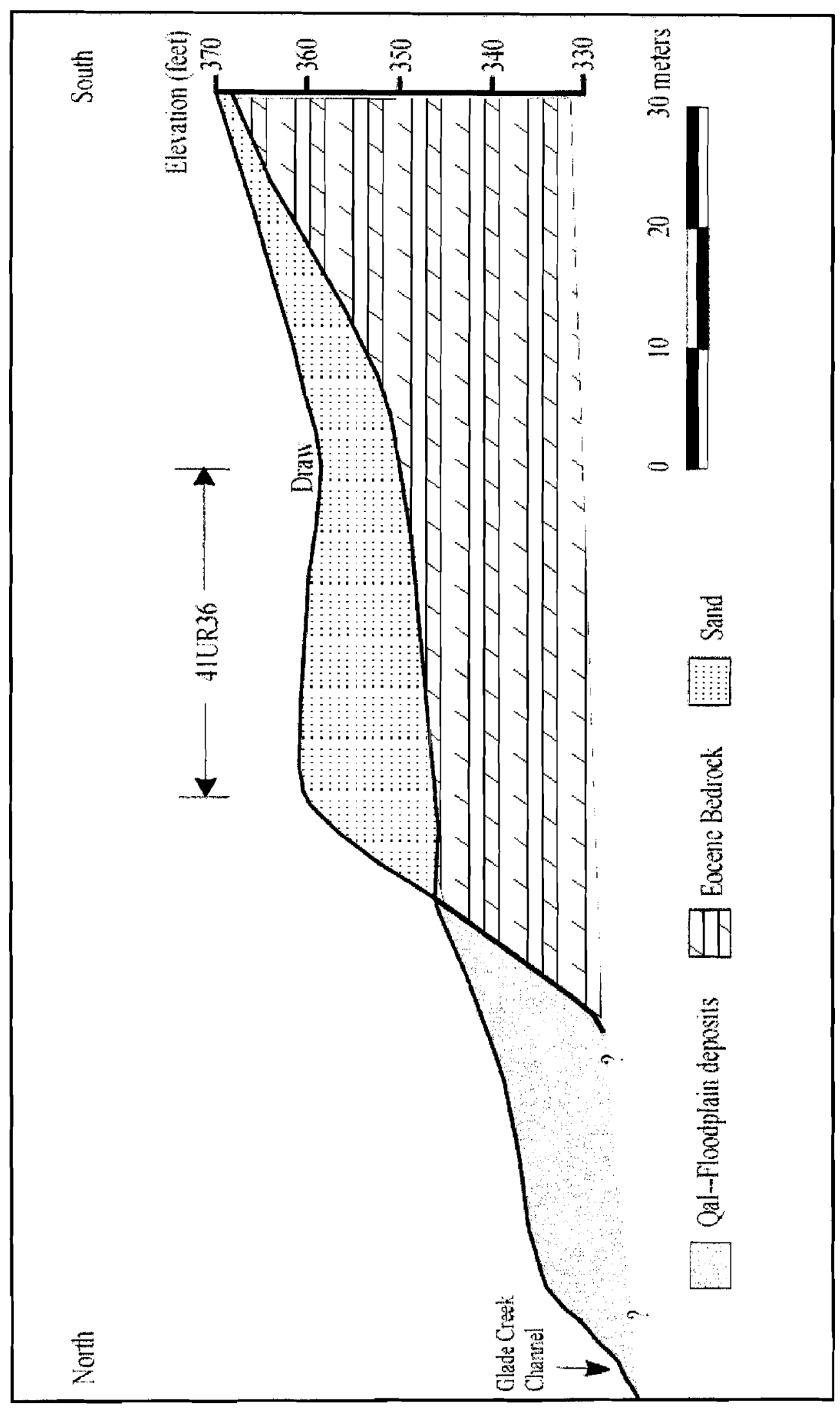

Figure 3. Schematic cross-section of Glade Creek Valley. 
between neighboringterritories. Manufacture of bifacial tools, pro-jectile points, and generalized cutting/scrapingtools was common. Additionally, burned rock features and groundstone implements were also common. Middle Archaic settlements are typically located within major stream basins, and are rarely present within smaller tributaries(Perttula et al. 1986:51). Late Archaic sites are more widely distributed, especially along minor tributary streams and springs. Group mobility during this period declined, and sedentism increased. Local lithic raw materials were heavily used during this final period.

The Archaic occupations of East Texas were followed by the Early Ceramic Period (200 B.C. to A.D. 800). During this period group size, sedentism, and social complexityincreased. Both small ephemeral sites and some fairly large and complex sites (e.g., Hurricane Hill; see Perttula 1999) become common. Subsistence technology included the development of agriculture, manufacture of pottery, and use of the bow and arrow. Reliance on plant gathering and hunting was still of primeimportance. Diagnostic artifactsduring this time period included late style Gary dart points, expanded stem arrow points, and sandy pastel grog-tempered ceramic wares such as Williams Plain, Cooper Boneware, Marksville, and Troyville Ceramics (Fields et al. 1993; Perttula 1999; Perttula and K enmotsu 1993; Perttula et al. 1993; Story 1990). Ceramic technologies of this period included the development of sandy paste wares and grog wares (Perttulaet al. 1986:53). This period has been recognized as an important transitionalstage from mobile hunter-gatherers to sedentary agriculturists.

The project area is located within the Sabine River basin within the Caddoanarcheological area (Perttula 1992). This area, commonly referred to as the Trans-Mississippian South (Perttulaand Bruseth 1998:1), encompasses portions of Texas, Louisiana, Arkansas, and Oklahoma. The Caddooccupied this region from around A.D.800 until the recent historic period A.D. 1860. The archeological expression of the Caddoan culture is divided chronologically into the Formative Caddoan(A.D. 800-1000), Early Caddoan(A.D. 1000- 1200), Middle Caddoan(A.D. 1200-1400), Late Caddoan(A.D. 1400- 1680), and Historic Caddoan (A.D. 1680-1860) (see Story 1990).

The Caddooccupancy of northeast Texas is marked by reliance on agriculture (e.g., use of cultigens such as corn), the development of utilitarian and stylisticceramics, and the bow and arrow, and use of settled residences (e.g., hamlets and villages). In addition to these developments, ranked societies, civic-ceremonial centers (multipleand single mound complexes), elaboratemortuary practices, and extensive trade networks, has been identified archeologically(Perttula and Bruseth 1998:2).

Nearly 5,000 recorded sites in N ortheast Texas are Caddo related (Perttula 1993a:124). Site patterningwithintheSabineRiver Basinlikely follows the same broad patterns described by Thurrnond (1990) for the Cypress Creek Drainage. Most Caddoan sites tend to occur in a valley setting, particularly along floodplain rises, terraces, and upland slopes and projections. The project area occurs on the edge of such an upland rise approximately $50 \mathrm{~m}$ from Glade Creek. Settlementsalso occur frequently with natural springs. Common site types include ceremonial mound centers, cemeteries, villages, hamlets, and farmsteads.

The upper Sabine basin contains numerous and important archeological deposits relating to Caddo cultural development. Early Caddo settlements are common along the Sabine River and its tributaries. Mound centers (burial and civic-center types) are also present, reflecting social stratification. Examples of these centers 
include the Colony Church site, Jamestown, and the Cox site (Perttulaet al. 1986:55). Hamlet settlements and farmsteads are also common occurrences along the Sabine at its tributaries. Burials and middens are frequent in these areas. Later period Caddoan sites are common along major drainages and along smallerdrainage basins and springs. Settlement types included small homesteads and farmsteads with burials, and regional mound centers (Perttulaet al. 1986:57).Perttula et al. (1986:58) suggest a connection between sites dating from A.D. 1400-1700 within the upper Sabine Basin to the Whelan and Titus phases as defined for the Cypress Creek Drainage ( see Thurmond 1990). This is based on the recovery of brushed, incised, and punctated ceramics from sites excavated in the upper Sabine Basin that correlate to the ceramics from the Cypress Creek drainage.

During the historic period, the Caddosubsisted on corn agriculture, native fauna, and native flora while living in dispersed villages or hamlets (Perttulaand Kenmotsu 1993:47). The southern Caddos were known as the Hasinai and to the north were known as the Kadohadacho. A Protohistoric Caddoan Period (A.D. 15401680) is coeval with the terminal Late Caddoan Period (see Story 1990), and corresponds to about the time of sporadic historic contact with European explorers(Perttula 1993b:148).

Historic Caddoan period (post-1680) sites are fewer in number (ca. 80-90) when compared to Late Caddoan/ProtohistoricPeriod sites. European materials at these sites includemetal arrow points, buttons, gun parts, and other metal items. Directly associated temporallydiagnosticitems of native manufacturefor this time include Patton Engraved, Poyner Engraved, Natchitoches Engraved, and some WomackEngraved pottery (Perttula 1993b:149). Encroachment by Europeans and other native groups during the eighteenth century and decimation by European-introduced diseases resulted in regrouping and consolidation of the Caddo. This has been well documented archeologically and ethnohistorically (see Perttula 1992). Eventually they were removed from Texas altogetherduring the midnineteenth century.

\section{PREVIOUS ARCHEOLOGICAL INVESTIGATIONS AT 41UR36}

Prewitt and Associates, Inc. recorded site 41UR36 in 1985 during the Big Sandy Project (Perttulaet al. 1986). This survey, which included portions of both Wood and Upshur Counties, was initiated prior to the construction a reservoir on Big Sandy Creek. Site 4 1UR36 was recorded as a multi-componentArchaic and Late CaddoanPrehistoricsite (Perttula 1986:106). Lithic materials were observed on an eroded roadcut on the west side of FM 1002, and shovel tests and surface walkovers revealed prehistoric ceramicsin a $1.100 \mathrm{~m} 2$ area overlooking the Glade Creek floodplain (Perttulaet al. 1986:278). Estimated site size was $7,500 \mathrm{~m}^{2}$, with an estimated $450 \mathrm{~m} 2$ of the site destroyed by the construction of FM 1002. Surface collections were made during the survey. Shovel tests and one 1-x-1-m test unit were excavated to examine the stratigraphic context and integrity of recovered materials.

On the basis of shovel test and test unit data, the site was estimated to be $80 \mathrm{~cm}$ in depth and possibly deeper, and potentially stratified. Late Caddoanceramics were recorded in the upper $30 \mathrm{~cm}$ while earlierArchaic Period lithic materials, including a Bell point, were concentrated between 30 and $80 \mathrm{~cm}$ (Perttula et al. 1986:277).A carinated bowl fragmentfrom 10 $20 \mathrm{~cm}$ below surface yielded a thermoluminescence date of A.D. 1450 (Perttula et al. 1986:278). Carinated bowls, bottles, and jars are present within the collection. Identified wares included brushed, incised, and punctated 
sherds. However, no slipped, polished, or engraved sherds were recovered (Perttula et al. 1986:278). Site recordersindicated that ceramics were much more common at this site than at most sites recorded during the Big Sandy Project, and that the ceramics are indicative of the Whelan or Titus Phase groups located within the Big Cypress Creek drainage (Perttula et al. 1986:278). Based on the potential site stratification between Archaic and Caddoan components, the relatively large number of ceramics, and their probable association with a midden, the site was regarded as potentiallyeligible for inclusionon the NRHP.

On October 21,1998, TxDOT archeologists Steve Ahr and Dianne Dismukes conducted a reconnaissanceof the project area and excavated five shovel tests (STPs 1-5) within the APE. One shovel test on the east side of FM 1002 revealed one piece of debitage at about $60 \mathrm{~cm}$ below surface. Four shovel tests on the west side of FM 1002 were negative. Based on the presence of a known, possibly intact and stratified site within the proposed project limits, it was determined that additional survey work was necessary, and that this work should include mechanical testing (i.e., backhoetrenching).

On March 29-31,1999, Prewitt and Associates, Inc. (PAI) was contracted to perform an archeological survey of the project area. Survey specifications included the mechanical excavation of prospection trenches in the APE in order to delineatethe horizontal and vertical boundaries of the site within the project area. Surveyors excavated six backhoe trenches and eight shovel tests (Figure4). The northwest part of the project area is comprised of wetlands, with little potential for undisturbed archeologicaldeposits. The northeast part of the project area was reported to have substantial disturbance (from a previous FM 1002 alignment), and also has little potential for intact materials (Gadus 1999:4). Gadus(1999) presents the details of these investigations, which defines the horizontal and vertical distribution of 41 UR 36 within the project area. This report also confirmed that site 41UR35, a ca. 1870s historic farmstead located approximately 300 meters south of $41 \cup R 36$, lies outside the projectlimits.

Buried archeological materials relating to 4.1UR36 were identified in backhoe trenches and shovel tests on the south side of Glade Creek. Artifacts were found in Trenches BT2a, BT3a, and BT 5a, as well as shovel tests 7-13, and were associated with Bowie sandy loam soils (Gadus 1999:5). Archeologicalmaterials identified from the site include debitage, burned ironstone rocks, a nutting stone, side/end scraper, burned nutshells, and a mussel shell fragment. The majority of materials were noted between $40-110 \mathrm{~cm}$ below surface, and were presumed to be associated with the Archaic component identified earlier (Gadus 1999:6).Additionally, a small, ca. 25-cm long cluster of burned rocks was recorded in the north wall of BT 2 at about $83 \mathrm{~cm}$ below surface, and is also suggested to be related to the Archaic component. The side/end scraper, from the backdirt of BT 5, from 50-100 cm, was also thought to belong to this component. No ceramics were noted at the site.

PAI concluded that the deposits could be stratified and intact with sufficient integrity to be potentiallyeligible for inclusion on the NRHP and merited designation as a SAL. Because of an ostensibly discrete, potentially intact Archaic component, additional testing was recommended to determineif the site could yield information to addressquestions about chronology, site function, and subsistence (Gadus 1999:7). Based on site size and distribution of identified cultural materials, TxDOT, in a letter dated May 7, 1999, proposed to SHPO that three 1-x-1-m test units be excavated on the east side of FM 1002, and one on the west 
side. It was also recommended that excavation units be excavated off the sides of reopened backhoe trenches. SHPO concurred with these recommendations on May 12,1999.

\section{ARCHEOLOGICAL TESTING OF 41UR36}

\section{Field Methods}

From September 27-30, 1999, archeologists Steve A hr, Lain Ellis, and Jesus Gonzales from TxDOT's Archeological Studies Program conducted archeologicalNRHPeligability testing of site 41 UR36. Bobby Jones and John Callisonfrom the Atlanta District O fficeand Jay Tullos, from the Tyler District Officeassisted. Johnny Haskins from the Linden Maintenance office served as backhoe operator. The purpose of these investigations was to assess the integrity of the portion of the site within the APE and determine whether or not that portion could contribute to the site's NRHPeligibility.

Four 1-x-1-m test units and one 1.5-x-0.5-m test unit were excavated across the site within the high probability areas identified during the previous survey (Figure 5). Units were handexcavated in arbitrary $10-\mathrm{cm}$ levels by shovel skimming and/or troweling, and all sediments were screened with 1/4-inch hardwarecloth. Information for each level was recorded in fieldbooks. When identified in situ, artifacts were mapped in the unit floor. Test unit and backhoe trench profiles, including soil color, texture, and any anomalousobservations were drawn and photographed. All excavated units and backhoe trenches were documented and all manually excavated proveniences were assigned to their respective geologic and pedologic contexts.

\section{Results}

Three backhoe trenches were opened on the east side of the roadway in the proposed rightof-way prior to the excavation of test units. Locations oftrenches were determined from high-probability/highartifact density areas identified during the survey. Three 1-x-1-m test units (TUs 1-3) and one 1.5-X-0.5-m test unit (TU 4) was excavated on the east side of FM 1002 off the walls of reopened trenches. Test Unit 5 was excavated on the west side of FM 1002 without an accompanying backhoe trench.

Profiles revealed ca. 1 to 1.4-m thick sandy loam depositsover clay subsoil. Excavation generally continued until the clayey subsoil was encountered. Total volume of hand-excavated material at the site was $4.4 \mathrm{m3}$. Each excavation unit is discussed below.

\section{Backhoe Trench 1 b(BTIb): Test Unit 1}

BT $\mathrm{lb}$ was positioned near the southern limit of the site in the vicinity of PA I's BT3a and excavated to $120 \mathrm{~cm}$.

Test Unit 1 was located off thenorth side of BT $1 \mathrm{~b}$ and was excavated to $100 \mathrm{~cm}$ below surface(Figure 6). A majority of the recovered materials consists of debitage. However, ceramics, FCR, a biface, and one projective point were also recovered. Most of recovered materials from this unit were concentrated between $20-50 \mathrm{~cm}$ below surface. A small burned rock feature was encountered at the base of level 6 and beginning of level 7 (designated Feature 1)and was excavated. All ceramicsin this unit $(\mathrm{N}=12)$ were recovered from the upper $50 \mathrm{~cm}$ of theunit.

The bulk of cultural materials from Test Unit 1 were associated with the upper $60 \mathrm{~cm}$ of deposits. The upper $20 \mathrm{~cm}$ consist of a dark yellowishbrown (10Y R3/4) sandy loam, which 


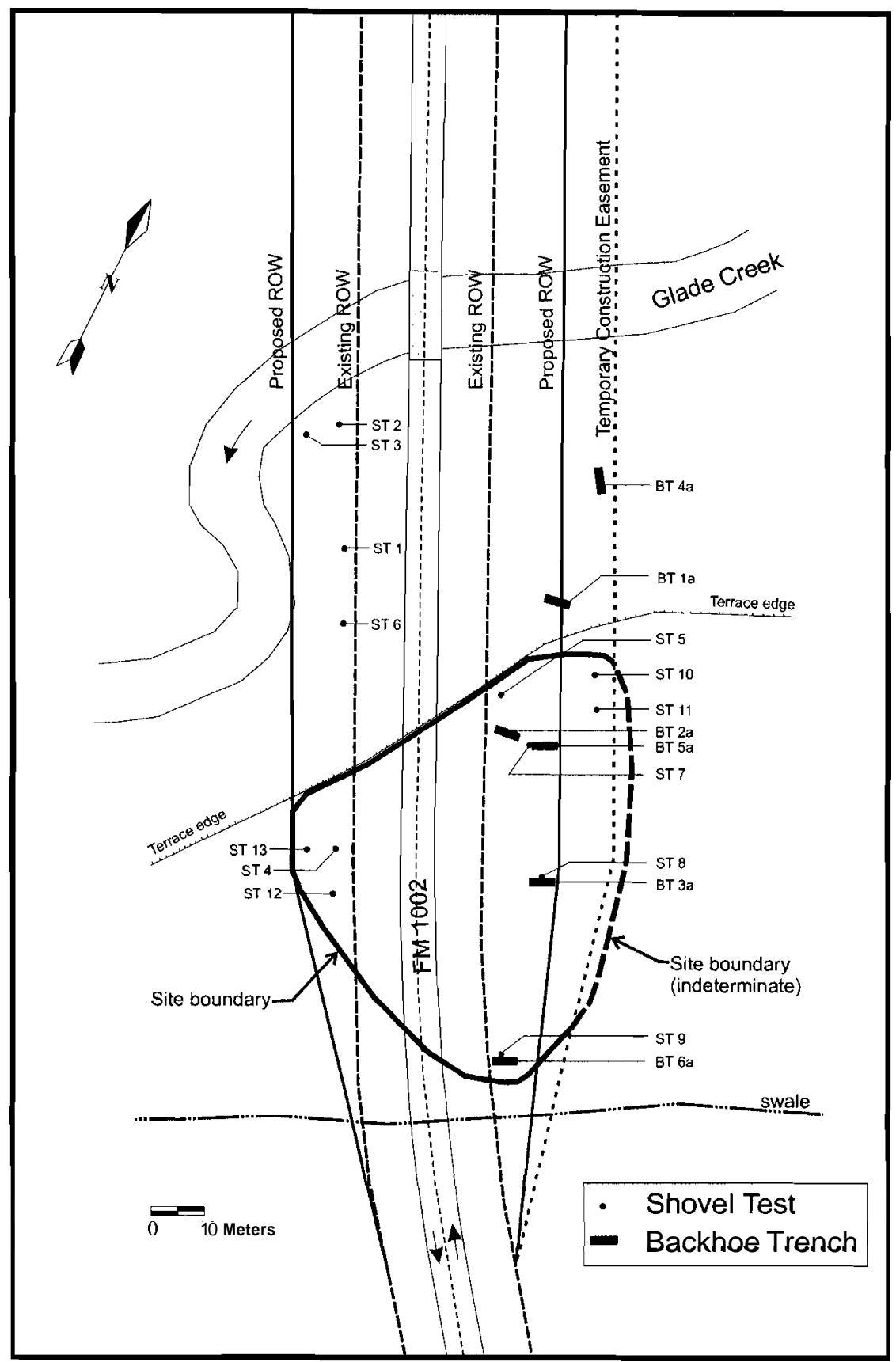

Figure 4. Shovel tests and backhoe trenches from TxDOT and PAI survey.

grades into a lighter yellowish brown (10Y R 4/ 6) loose sand horizon until about $60 \mathrm{~cm}$ below surface. The dart point and biface were recovered from 60 to $90 \mathrm{~cm}$ below surface, where deposits consist of compacted yellowish brown (10Y R 5/6) mottled sand and exhibit a significantincrease in clay and silt content.
This horizon grades into a less compacted, light yellowish brown (10Y R6/4) E-horizon from about $80-120 \mathrm{~cm}$, where the sterile claypan Bt horizonis located. Some mottles areevident. Disturbances noted during excavationinclude krotovinas, root casts, and bug casts in the upper $60-80 \mathrm{~cm}$. 


\section{Backhoe Trench 2b (BT2b):Test Unit 2}

BT 26 was located at the northeast comer of the site, within the edge of a previously cleared and plowed field. This trench was placed adjacent to PAI's shovel test \#10, which yielded debitage, a nutting stone, and burned rocks.

Test Unit 2 was placed on the west wall of the trench and excavated to $130 \mathrm{~cm}$ below surface. Debitage was present throughoutall but the last level. Two ceramic sherds were found in TU2, one in Level 1 and one in Level 5. A total of two dart points were recovered from level 11 and 13. FCR and one piece of bone were also recovered.

The artifact modal distributionis level 2 (10-20 $\mathrm{cm}$ ), with a general trend toward a decrease in artifactdensity with increasing depth. The highest density of cultural materials was recovered from the upper ca. $30 \mathrm{~cm}$ of deposits, which consists of a dark yellowish brown (10YR3/6) sandy loam, and is identified as the plowzone(Ap-horizon). From 30-60 cm, this horizon gradesinto a lighteryellowish brown (10YR4/4), and is less compacted and is associated with a dramatic decrease in the numbers of recovered materials, particularly debitage. Root casts, mottles, and other disturbances were noted between $60-80 \mathrm{~cm}$. Between 70 and $130 \mathrm{~cm}$, the sand is loose, and consists of a yellowish brown (10YR5/6)Ehorizon. At about $100 \mathrm{~cm}$, clay larnellae (7.5YR4/6)are present, and increase dramatically at around 110 to $120 \mathrm{~cm}$ (Figure 7). The two dart points were recovered from within these lamellae. At $130 \mathrm{~cm}$, compact sandy clay subsoil was encountered and excavation halted. No archeological features were identified, although several isolated pieces of Femg and burned sandstone fragments were encountered throughout the unit and likely represent the remains of disarticulated and vertically displaced features.
Backhoe Trench 3b (BT3b):Test Units 3 and 4

BT 36 was excavated approximately 7 meters east of the right-of-way fenceline, and 12 meters west of BT $2 b$. We attempted to align this trench along PAI's BT2a, where several flakes and a small burned rock cluster had been documented $83 \mathrm{~cm}$ below surface.

PAI's previous trench could not be detected on the surface, so a ca. 9-x-4-m area was scraped to $15 \mathrm{~cm}$ below surface. No trench outline was detected and no cultural features were observed within the scrapes. Based on previous survey photographs, location of the previous trench was identified and re-excavated, along with a $30 \mathrm{~cm}$-wide strip of previously unexcavated ground. Within the newly excavated $30 \mathrm{~cm}$-wide strip, the small burned rock feature (designated as Feature 2), was encountered at $80 \mathrm{~cm}$ below surface (Figure 8). This small burned rock cluster (now in plan view) was the feature noted in the previous trench profile during the PAI Survey. Excavation was halted and the feature was documented. Test Units 3 and 4 were then excavated to document the feature and the surrounding matrix.

Test Unit 3 was located on the north wall of the trench adjacent to the uncovered feature and was excavated to $100 \mathrm{~cm}$ below surface. Debitage was concentratedin the upper $30 \mathrm{~cm}$ of the profile, decreasing in quantity with depth. FCR was recovered from $30-40 \mathrm{~cm}$, ocher was located between $50-60 \mathrm{~cm}$, and one core and one abrader were recovered from between $80-90 \mathrm{~cm}$. One small feature (designated Feature 3), consisting of a small cluster of burned Ferrous Magnesium (FeMg)concretions, was recorded at $50 \mathrm{~cm}$ below surface.

Test Unit 4 was excavated in the floor of the trench at a depth of $80 \mathrm{~cm}$, adjacent to the south wall of Test Unit 3. The purpose of this test unit 


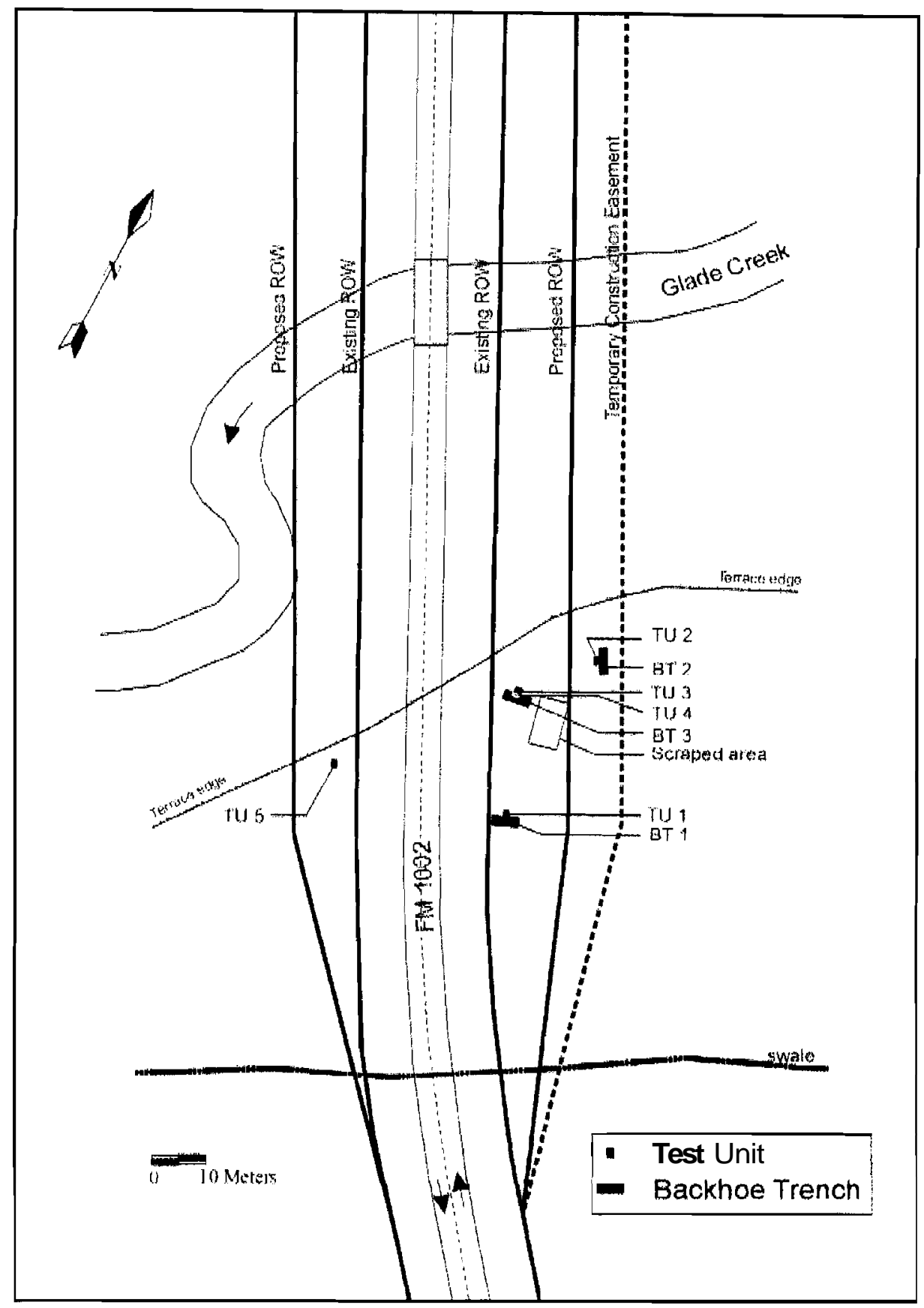

Figure 5. Backhoe trenches and test units from TxDOT archeological testing.

was to excavate the matrix associated with

Feature 2. A total of two levels, centering on the feature, were excavated in T.V. 4. From 80$90 \mathrm{~cm}$, feature characteristicswere recorded (no feature rocks were collected). In addition, one flake, one abraded stone, and one incised pebble were recovered in this unit. Only one piece of debitage, from 90-100 cm, was recovered.

The profile in BT $3 \mathrm{~b}$ was similar to that of BT 1b. The upper $40 \mathrm{~cm}$ of soil in the profile was compact. Below $40 \mathrm{~cm}$, the soil was less 


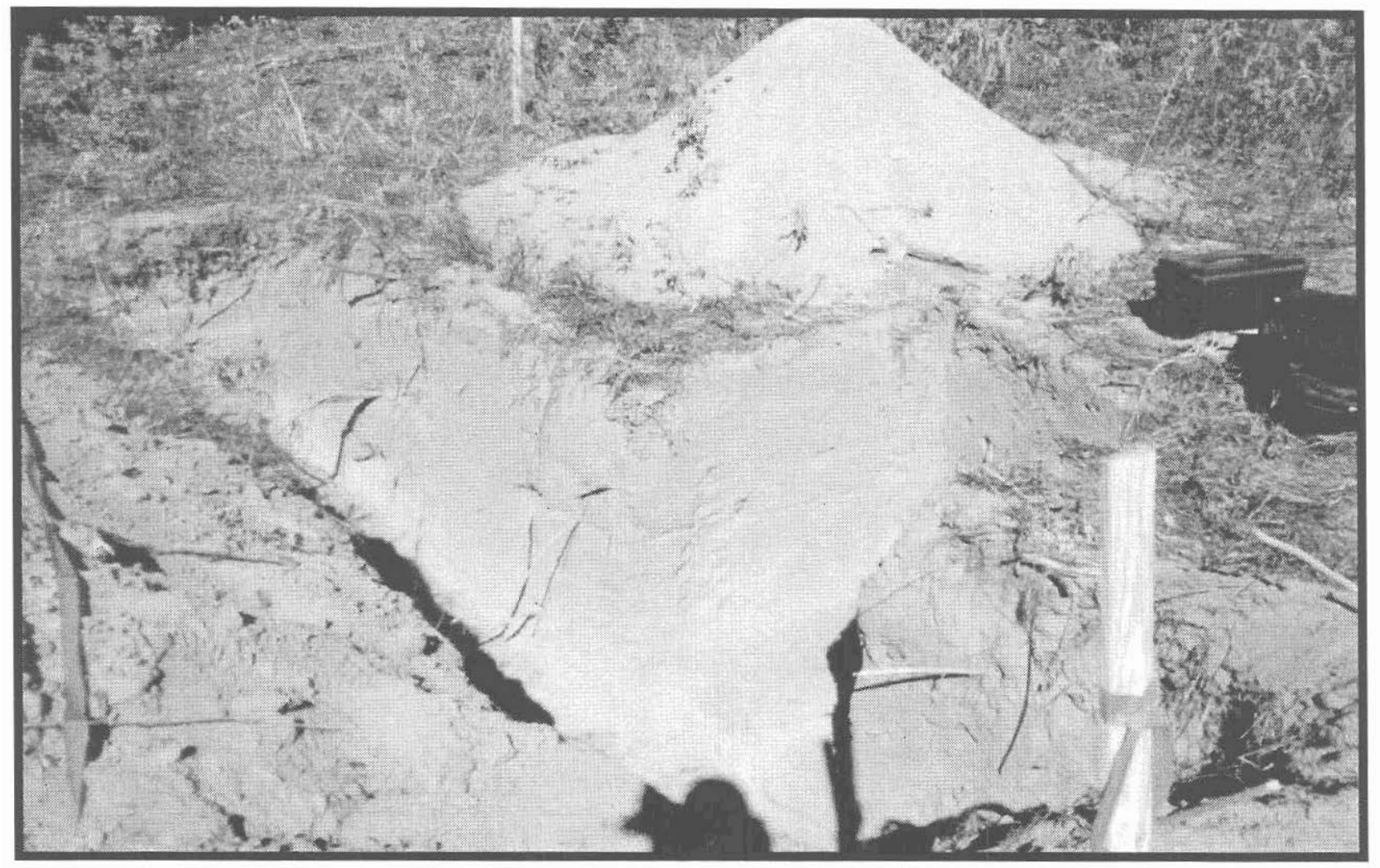

Figure 6. West view of B ackhoe Trench $1 b$ and Test U nit 1.

compact. Similar to other units. the majority of debitage, was recovered from these upper deposits. Between $60-70 \mathrm{~cm}$, and associated with adecrease in artifact content. the profile is mottled as it grades into the lighter colored (1 OY R 5/6) E-horizon. From about 70-100 $\mathrm{cm}$, silt and clay content increase, and several clay lamellae have formed. These lamellae are at the same depth as the core and abrader from Test Unit 3, and an abraded stone, incised pebble, and debitage from Test Unit 4.

\section{$\underline{\text { Test Unit } 5}$}

Test Unit 5 was located on the west side of FM 1002 on a small rise between the Glade Creek floodplain to the north and a small swale to the south. This unit was excavated to $100 \mathrm{~cm}$ below surface, where dense compact clay was encountered. No artifacts were recovered from $90-100 \mathrm{~cm}$. The majority of artifacts from this unit consist of debitage, which increase in number steadily up to $50 \mathrm{~cm}$, below grand surface then decrease steadily until $80 \mathrm{~cm}$ below surface. One legume bean was recovered from $40-50 \mathrm{~cm}$. It does not appear to be charred, and is likely a native variety and not domesticated (Karen Clary, personal communication 2000). No features were identified in this unit.

The profile from this unit differs from previous unit profiles. The upper $30 \mathrm{~cm}$ consists of loose coarse sand (10Y R 5/4) that becomes increasingly compacted with depth. From 30 to 80 $\mathrm{cm}$, the profile consists of very compact fine sand (10Y R 5/6). Interestingly, most of the debitage is associated with this more compact horizon. The profile becomes slightly mottled from 80-95 cm (10Y R6/4), which overlies very fine sandy/silty clay (10Y R 5/8 and 10Y R6/6). A significant increase in the amount of FeMg 
concretions from $80-100 \mathrm{~cm}$ was noted in the field. The excavation of thisunit was terminated when clay was encountered.

\section{CULTURALMATERIALS}

\section{Feature Descriptions}

Three burned rock features were identified and recorded in test units. Each feature is discussed below (see Table 1).

\section{Feature 1}

Feature 1 was encountered at the bottom of level $6(60 \mathrm{~cm})$ during the excavation of TestUnit 1. It consisted of only four burned sandstonerocks, with an estimated feature diameter of $30 \mathrm{~cm}$. Burned sandstone crumbs occurred sporadically in level 7 fill. No bone, shell, or charred materials were observed with the feature. However, an Ellis-like dart point from level 7 was recovered from the excavated feature fill. During the excavation of Test Unit 1 , a few isolated $\mathrm{FeMg}$ fragmentswere encountered in the levels above this feature. Most of these fragmentsappeared to be the remains of disarticulatedand vertically displaced features.

\section{$\underline{\text { Feature } 2}$}

Feature 2 was initially identified in the north wall profile of PAI's BT2a, at $83 \mathrm{~cm}$ below surface. Test Unit 4 was excavated through the feature. The feature had a diameter of $25 \mathrm{~cm}$, and consisted of a small cluster of burned FeMg fragments (Figure 10). One rock is fist-size, while the remaining 12 rocks are small (ca. 5$10 \mathrm{~cm}$ diameter), friable, and reddened. No hone, shell, charred materials, or discolored sediment was observed with the feature. Materialsfrom the same level as the feature include debitage, a hematite stone, and an incised pebble. Additionally, a quartzitecore and an abrader stone were recovered from the same level in the adjacent Test Unit 3.

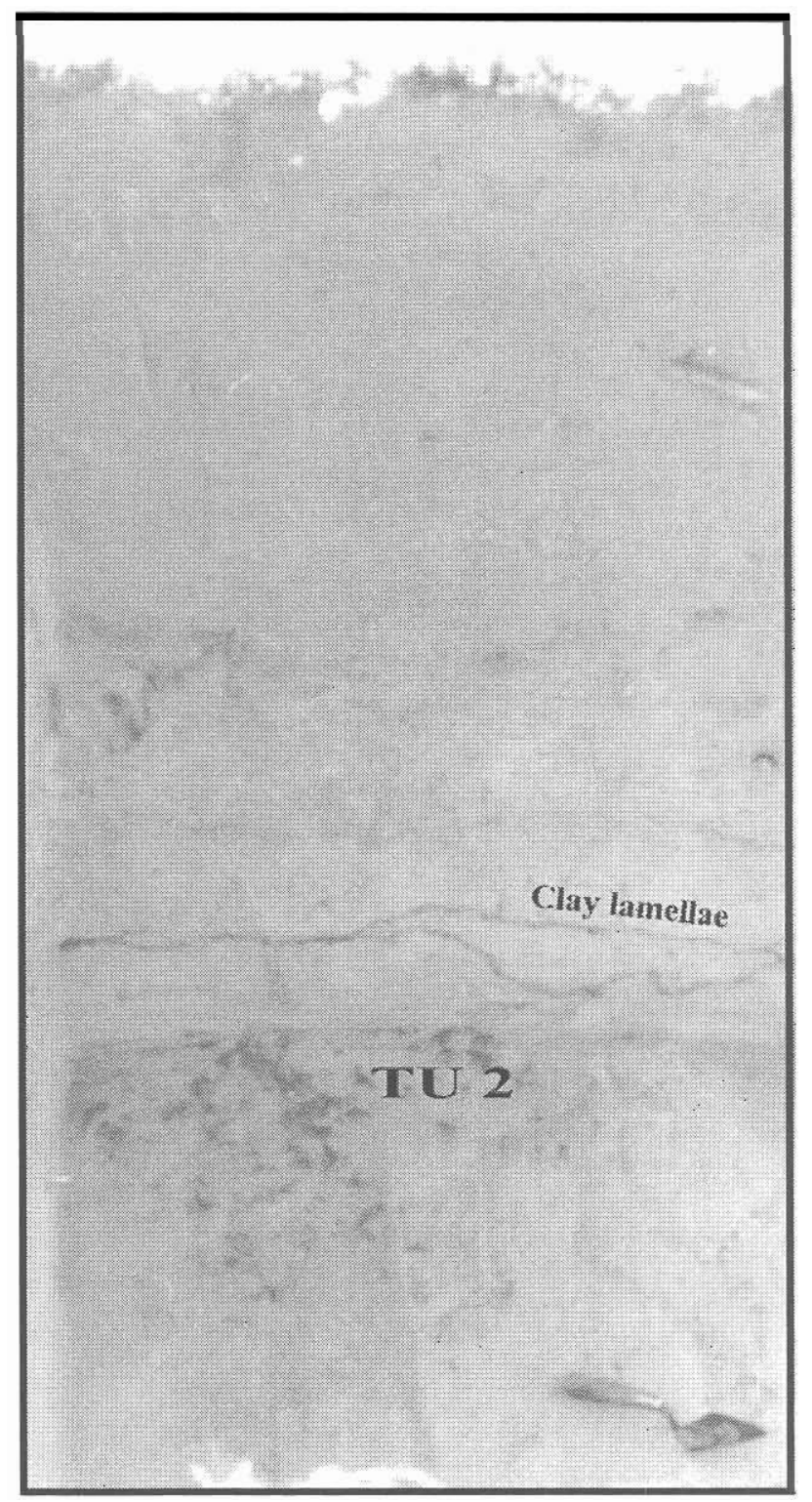

Figure 7. Test Unit 2 west profile.

\section{$\underline{\text { Feature } 3}$}

Feature 3 was identified in Test Unit 3 at $50 \mathrm{~cm}$ below surface (Figure 11). The feature consists of three large $(\mathrm{ca} .10 \mathrm{~cm}$ ) diffuse burned $\mathrm{FeMg}$ fragments. One edge-modified flake was found in the level above this feature. There is a corresponding decrease in debitage at the feature level, and no bone, shell, charred materials, or discolored sediment was observed. 


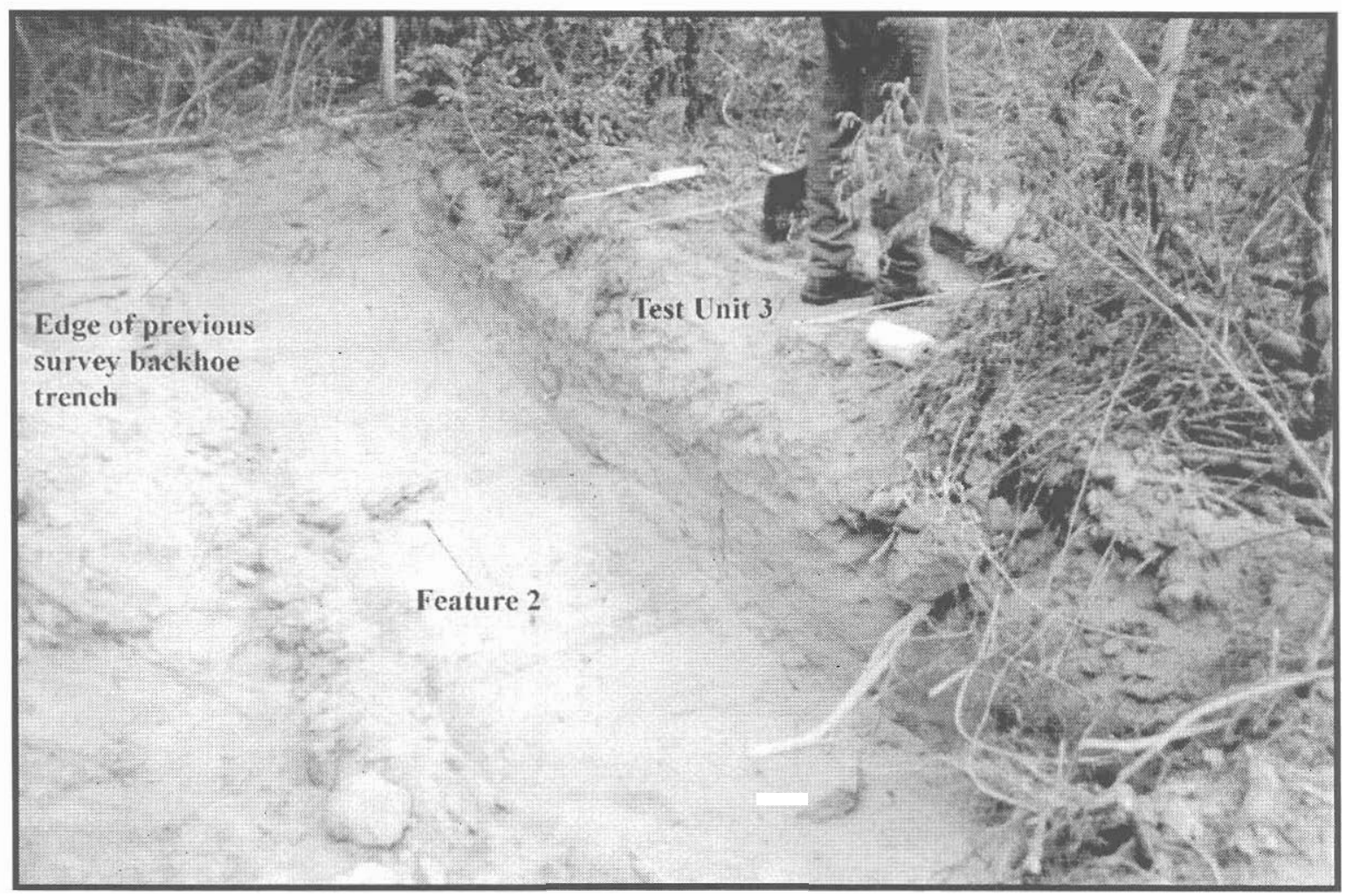

Figure 8. West view of Backhoe Trench 3b, Test Unit 3, and Feature 2.

\section{Artifact Descriptions}

Descriptivedata for each artifact class are presented below and are summarized in Tables 2 and 3.

Ceramics $(\mathrm{N}=12)$

Ten aboriginal ceramics were recovered From Test Unit 1 and two from Test Unit 2 (Figure 12). All ceramics were recovered from the upper $50 \mathrm{~cm}$ of deposits. Analysis data for each sherd is presented below (Table 2). Half of the total number of sherds was recovered from Level 3 in Test Unit 1. Body sherds comprised nearly the entire assemblage, except for a single rim sherd in Test Unit 1. Six of thesherds are plain, four exhibit brushing, and two are incised. Grog is present in eight sherds, sand is dominant in seven sherds, and bone is present in two sherds. All brushed sherds and one incised sherd contain grog temper while most of the plain sherds are dominated by sand. Sherd thickness ranges from 0.4 to $0.8 \mathrm{~cm}$, and average sherd thickness is $0.63 \mathrm{~cm}$.

\section{Bifacially Flaked Tools $(\mathrm{N}=4)$}

Bifaces are tools with flakes removed from $50 \%$ or more of each face. They are reduced from a larger flake or core in a reduction process that proceeds in a series of steps. Thinner bifaces are associated with light duty activities (e.g., cutting and piercing)involved in hunting and game processing, while larger, thicker bifaces are characteristic of heavy-duty tasks such as butchering, pounding, and chopping. Four bifacial tools were recovered, and are illustrated in Figure 12.

One late-stage bifaee was recovered from Test Unit 1, Level 9. This artifact was not associated with any features. It is $7.2 \mathrm{~cm}$ long, 4.1 $\mathrm{cm}$ wide at the distal end, and $1.9 \mathrm{~cm}$ thick. 


\begin{tabular}{|l|l|l|l|l|l|}
\hline $\begin{array}{l}\text { Feature } \\
\text { No. }\end{array}$ & Unit & Level & $\begin{array}{l}\text { Diameter } \\
(\mathrm{cm})\end{array}$ & Description & $\begin{array}{l}\text { Possible associated } \\
\text { materials }\end{array}$ \\
\hline F1 & I & $\mathbf{6}$ & 30 & $\begin{array}{l}\text { Four bumed sandstone rocks } \\
\text { andnumerous friable crumbs. }\end{array}$ & Ellis-like dart point from level 7. \\
\hline F2 & 4 & $\mathbf{9}$ & $\mathbf{2 5}$ & $\begin{array}{l}\text { Small cluster of burned, friable, } \\
\text { reddened ironstone fragments. } \\
\text { One fist-size rock and 12 rocks } \\
\text { that are 5-10 cm in diameter. }\end{array}$ & $\begin{array}{l}\text { Hematite stone. Incised } \\
\text { pebble. abrader stone }\end{array}$ \\
\hline F3 & $\mathbf{3}$ & 5 & 20 & $\begin{array}{l}\text { Three large (10-cm) diffuse } \\
\text { ironstone fragments. }\end{array}$ & $\begin{array}{l}\text { Edge-modified flake. Decrease } \\
\text { in debitage density in thislevel. }\end{array}$ \\
\hline
\end{tabular}

Table 1. Feature data from 41UR36.

This axe-like tool was manufactured from medium-grained gray quartzite material and may have been hafted.

One Ellis-likedart point was recovered from Test Unit 1,Level 7, inassociation with Feature 1. It is $3.5 \mathrm{~cm}$ long, $2.3 \mathrm{~cm} w i d e$, and $0.85 \mathrm{~cm}$ thick. It is comprised of siliceous material and banded with small quartzite inclusions. The
Ellis-like dart point type likely dates from the Middle to Transitional Archaic Periods (2000 B.C. - A.D. 700), and was present at the George C. Davis Site and Tankersley Creek Site (Turner and Hester 1993:113).

A Gary Point (2500 B.C. to A.D. 700-800) was recovered from Test Unit 2, Level 11. It is 4.5 $\mathrm{cm}$ long, $2.2 \mathrm{~cm}$ wide. and $0.65 \mathrm{~cm}$ thick. It is

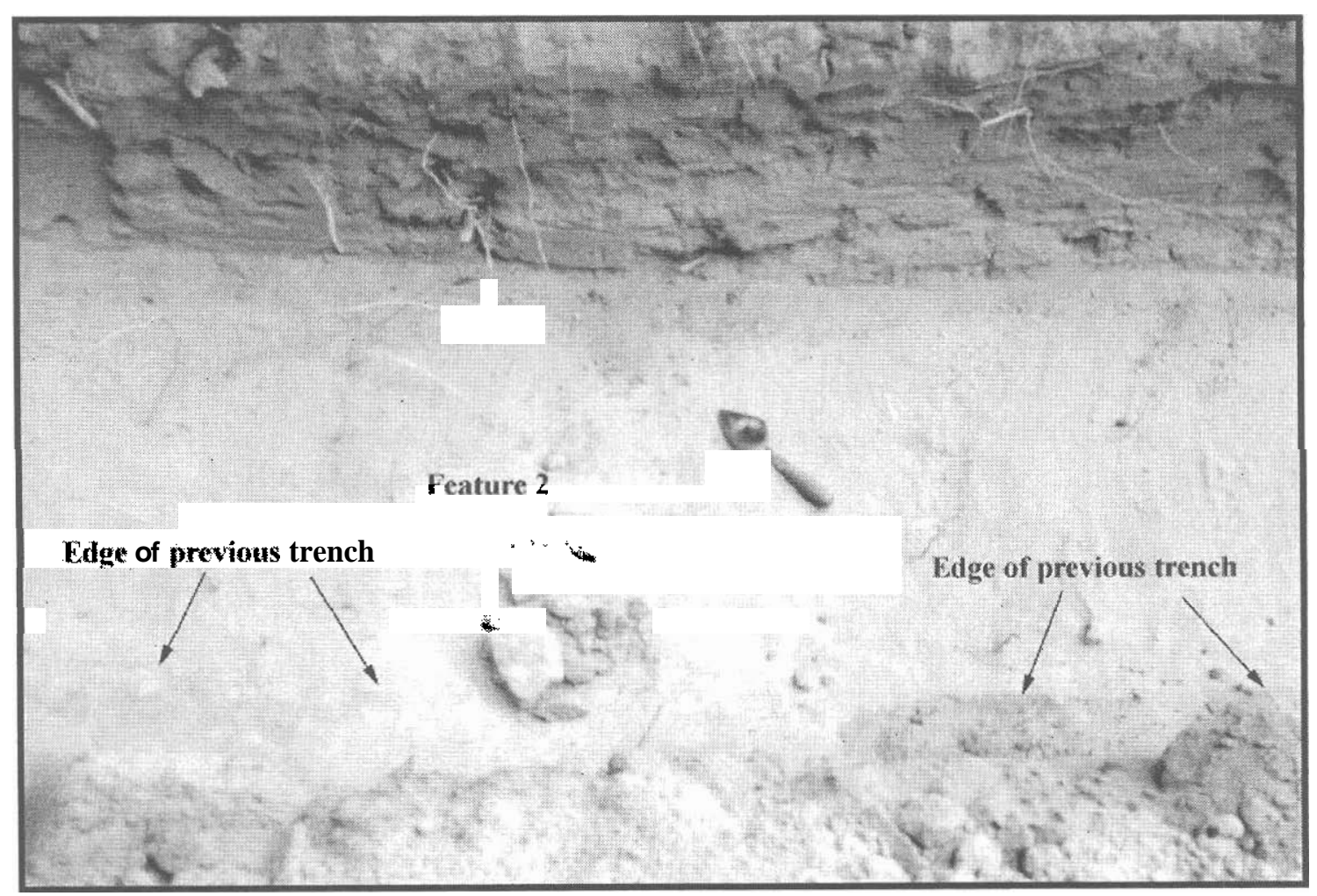

Figure 9. View of Fea ture 2 in Backhoe Trench $3 b$. 
manufacturedfrom very fine-grained tan quartzite material. This artifact was not associated with any features.

Finally, a dart point base, which resemblesthe Middle Archaic Yarbrough type, was recovered from Test Unit 2. Level 13. It is $2.2 \mathrm{~cm}$ long, $2.6 \mathrm{~cm}$ wide. and $0.9 \mathrm{~cm}$ thick. The proximal end of thepoint is missing. The point base is comprised of heat-treated reddish petrified wood, is broken laterally across the midsection, and is lenticular in cross-section. The base is slightly ground, with a shouldered, contracting stem. This artifact was not associated with any features.

\section{Grounded/Pecked/Incised Stone Artifacts ( $N=3$ )}

This tool class consists ofartifacts modified and shaped by abrasion, grinding, pecking, and/or other impacts, with other hard materials, rather than through a flake reduction process. Three tools in the assemblage fall into this category (Figure 14).
One incised/brushed hematite stone was recovered from Test Unit 4, Level 9. in possible association with Feature 2. It is $7.3 \mathrm{~cm}$ long. $5.8 \mathrm{~cm}$ wide. and $2.4 \mathrm{~cm}$ thick. Athin. soft. oxidized coating is present on the outside of the artifact. and numerous striations are evident on both sides of therock.

A small abrader stone was recovered from Test Unit 3, Level 9. in possible association with Feature 2. It is $3.8 \mathrm{~cm}$ long, $2.9 \mathrm{~cm}$ wide, and $2.0 \mathrm{~cm}$ thick. The two ends have varying degrees of impact/peck marks. Also. one side of the stone appears to he grounded and smoothed, creating a slight facet.

Finally, a fragment of an incised rock was recovered from Test Unit 4, Level 9, in possible association with Feature 2. It is $2.1 \mathrm{~cm}$ long, 1.9 wide, and $1.8 \mathrm{~cm}$ thick. This quartzitestone was probably tabular-el ongatein shape, but now both ends are missing. Apronounced $v$-shaped groove runs across the face. Aseries of smallerstriations are

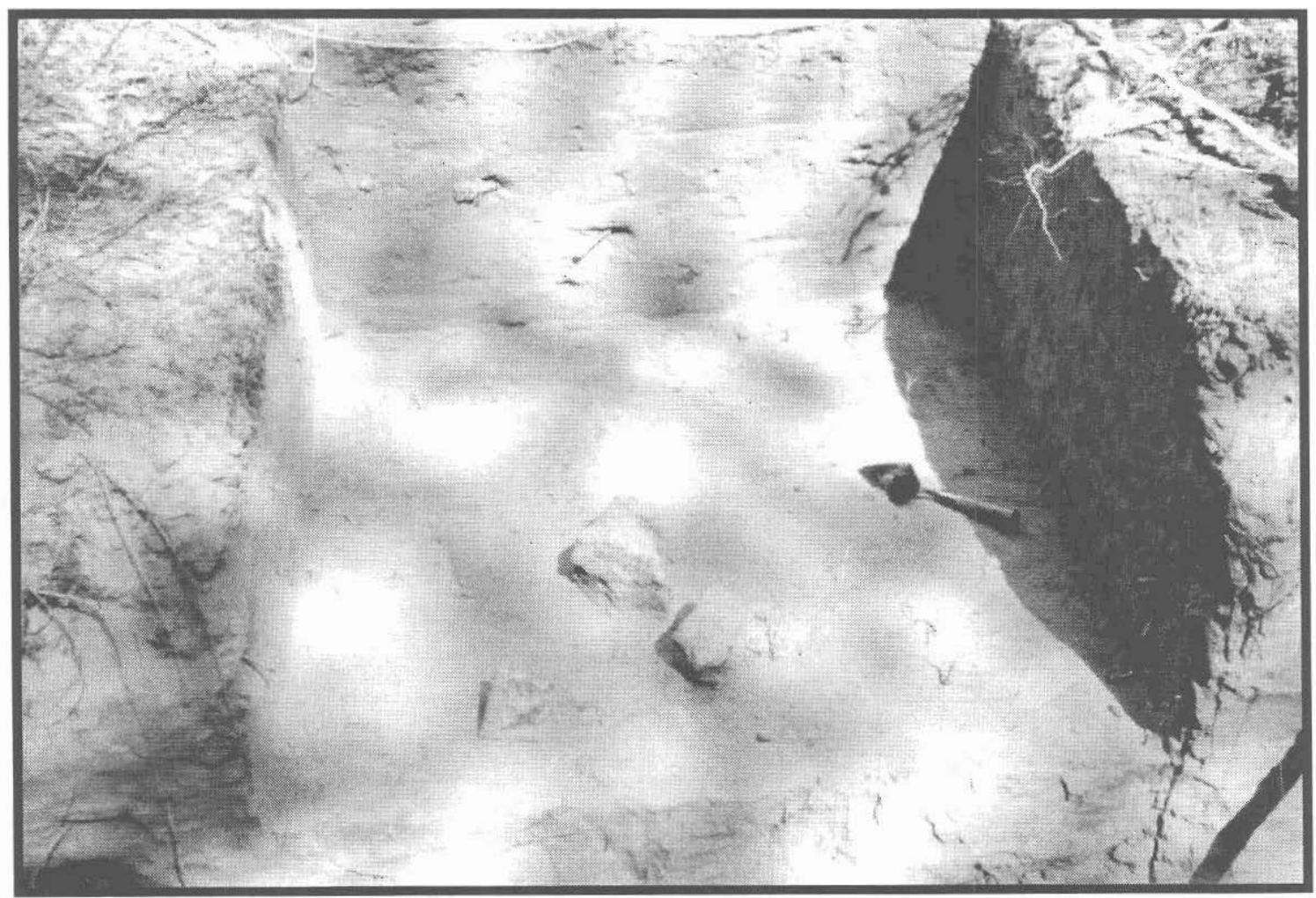

Figure 10. View of F eature 3 in Test Unit 3. 
also present on the faceted edge of the rock, and are oriented perpendicular to the larger groove. This faceted edge is smoothed.

\section{Edge-Modified Tools ( $\mathrm{N}=1$ )}

This category of tool includes flakes that are detached from a core and are trimmed or utilized for a variety of scraping, sawing, and slicing activities. These tools are usually expedient in nature with little modification from their original form (Ahlerand Swenson 1985:34). Edge-modifiedflakes exhibit non-invasiveflake scars covering less than 50 percent of each face. Use-wear generally consists of step flaking, rounding, smoothing, polish. and microflake scars. This wear can occur on any edge of the flake, eitherunifacially or bifacially, and on single or multiple margins of one or more faces.

Only one recovered artifact from 41UR36 falls in this class, and was recovered from Test Unit 3, Level 4. It is $9.8 \mathrm{~cm}$ long, $5.2 \mathrm{~cm}$ wide, and $1.5 \mathrm{~cm}$ thick, and is made from poor quality siliceous wood. Margins on both faces exhibit varying degrees of step flaking. Part of one edge is unifacially step flaked, indicating a scraping activity.

\section{Cores $(\mathrm{N}=2)$}

Two cores were recovered from the site. The first was recovered from Test Unit 1,Level 2. It is $3 \mathrm{~cm}$ long, $2.7 \mathrm{~cm}$ wide, and $2.5 \mathrm{~cm}$ thick. It is made of very blocky, cherty to fine-grained quartzite material. Two blocky flakes have been removed from one face.

The second core was recovered fromTest Unit 3 , Level 9. It is $7 \mathrm{~cm}$ in length, $3.2 \mathrm{~cm}$ wide, and $2.8 \mathrm{~cm}$ thick. It is made from dense medium-grained quartzite material. Two long flakes have been detached fromit and it is prismatic in appearance.

\section{Lithic Debitage ( $\mathrm{N}=263$ )}

A total of 263 pieces of lithic debitage were recovered from test excavation units and analyzed. Four attributes were considered part of thisanalysis: material type, degree of cortex, flake type, and platform type. The purpose of this analysis was to elucidate patternsin tool manufactureand reconditioningactivities.

\section{Material Type}

Forty-nine percent of the debitage assemblage is comprised of quartzite $(\mathrm{N}=130)$. No distinc

\begin{tabular}{|l|l|l|l|l|l|}
\hline Part of vessel & Unit & Level & Temper & Decoration & Thickness (cm) \\
\hline Everted rim & 1 & 2 & Sand/grog & Brushed & 0.7 \\
\hline Body & 1 & 2 & Sand/bone & Plain & 0.5 \\
\hline Body & 1 & 3 & Bone/grog & Brushed & 0.5 \\
\hline Body & 1 & 3 & Grog & Brushed & 0.7 \\
\hline Body & 1 & 3 & Sand & Plain & 0.7 \\
\hline Body & 1 & 3 & Sand & Plain & 0.8 \\
\hline Body & I & 3 & Sand & Plain & 0.5 \\
\hline Body & 1 & 3 & Grog & lncised & 0.6 \\
\hline Body & 1 & 4 & Sand/grog & Plain & 0.4 \\
\hline Body & 1 & 5 & Sand & Incised & 0.8 \\
\hline Body & 2 & 1 & Grog & Plain & 0.7 \\
\hline Body & 2 & 5 & Grog & Brushed & 0.7 \\
\hline
\end{tabular}

Table 2. Ceramic Data from 41UR36. 


\begin{tabular}{|l|l|l|l|l|l|l|} 
Artifact & Unit & Level & Length & Width & 'Thickness & Comments \\
\hline Biface & 1 & 9 & 7.2 & 4.1 & 1.9 & Late-stage;axe-like \\
\hline Dart point & 1 & 7 & 3.5 & 2.3 & 0.85 & Ellis-like(Middle Archaic) \\
\hline Dart point & 2 & 11 & 4.5 & 22 & 0.65 & Gary point(Late Archaic) \\
\hline Dart point & 2 & 13 & 22 & 2.6 & 0.9 & $\begin{array}{l}\text { Dart point base only. Resembles } \\
\text { Yarbrough (Middle Archaic) }\end{array}$ \\
\hline Hematite stone & 4 & 9 & 7.3 & 5.8 & 2.4 & $\begin{array}{l}\text { Brushed; 1.e., pant stone; oxidized } \\
\text { coating and numerous striations }\end{array}$ \\
\hline Abrader stone & 3 & 9 & 3.8 & 2.9 & 2.0 & Impact marks on end; one faceted side \\
\hline $\begin{array}{l}\text { Incised rock } \\
\text { Edge-modified } \\
\text { flake }\end{array}$ & 4 & 9 & 2.1 & 1.9 & 1.8 & $\begin{array}{l}\text { V-shaped groove on face; smaller } \\
\text { striations on faceted edge }\end{array}$ \\
\hline
\end{tabular}

Note: Tool measurements are in em.

Table 3. Lithic tool data from 41UR36.

tion was made between coarser and finegrained quartzite. Most of the finer grained quartzites were reddish in color. Chert materials comprise $44 \%$ of the debitageassemblage. Chert debitage was sorted by color, and the most common type was gray chert, which comprised $18 \%$ of the entire debitageassemblage. Various white, red, and brown/tan colored pieces of debitage collectively comprise approximately $23 \%$ of the overall assemblage. Petrified/siliceouswood debitage makes up 3.8\% of the assemblage, and ironstone comprises $2.2 \%$.

\section{Degree of Cortex}

Degree of cortex refers to the amount of cortex (weathering rind of the rock) that remains on the dorsal side of a detached flake. As cores and tools are gradually reduced in size, the flakes detached from these should retain less and less cortex, are generally smaller in size, and are usually produced by softhammerpercussion or pressure flaking techniques. Degree of cortex therefore serves as a rough approximation of flake size and also an indicator of various stages in the tool reduction process. Three categoriesare used: primary corticated flakes, secondary corticated flakes, and tertiary (interior) flakes. Primary flakes contain cortex on the entire dorsal surface. Secondary flakes contain corticated and non-corticated areas on the dorsal surface, and tertiary flakes contain no cortex. Within the debitage assemblage from 4 1UR36, primary flakes comprise $4.6 \%$, secondary flakes comprise $18.3 \%$, and tertiary flakes comprise $77.2 \%$.

\section{Flake Type}

All debitage were classified according to flake type, an indicator of the method of manufacture and stage of tool production. Flake types within the assemblage are distributed fairly evenly between biface thinning flakes (19\%), hardhammer percussionflakes (17\%), softhammer percussionflakes (20\%), flakes with missing platforms (18\%), and shatter/ angulardebris (22\%). Very few (1.9\%) were identified as pressureflakes, which is likely a bias due to screen mesh size.

\section{Platform Type}

Platform types were also recorded for all recovered debitage. Nearly half of the flakes within the assemblage (49.8\%) are missing 


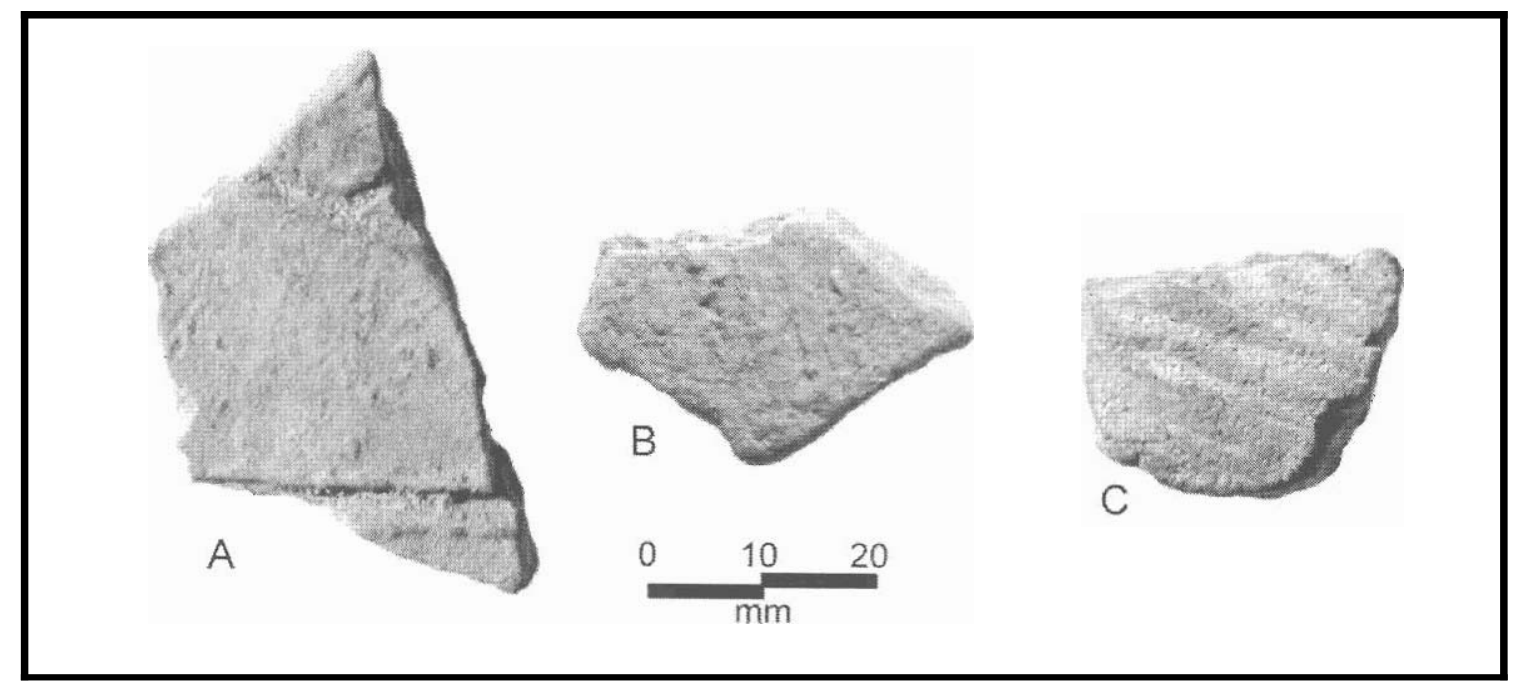

Figure 11. Selected ceramic sherds from 41UR36: (a) incised, TU 1, LV 3; (b) brushed, TU 1, LV 3; (c) brushed, TU 2, LV 5.
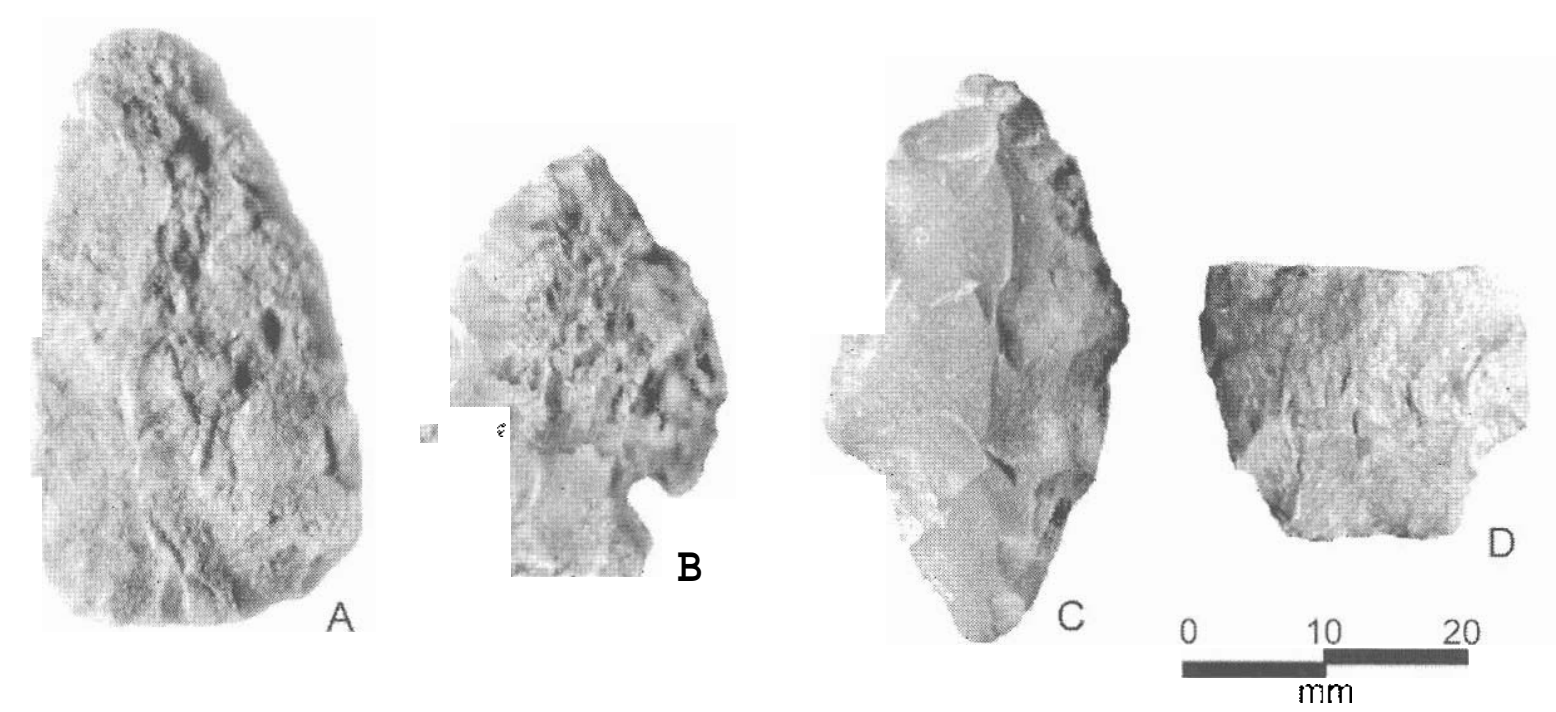

Figure 12. Bifacially flaked tools from 41UR36: (a) biface, TU 1, LV 9; (b) Ellis-like dartpoint, TU 1, LV 7; (c) Gary dartpoint, TU 2, LV 11; (d) Yarbrough-like dartpoint base, TU 2, LV 13.

platforms. This count includesall shatter (angulardebris),those flakes missingplatforms that could not be typedbut retain flake characteristics, and typed flake types that that are missing platforms. Faceted (17.8\%), flat (12.9\%), and lipped (12.9\%) platforms comprise the remaining pieces of debitage.

\section{Debitage Distribution}

Thirty nine percent $(\mathrm{N}=102)$ of debitage was recovered from Test Unit 1, which also had the highest flake density of any hand-excavated unit (102 per m3). Debitage density was lower at the north end of the site in Test Unit 2 (70 per m3),Test Unit 3 (49 perm'). and Test Unit 4 (20 per $\mathrm{m} 3$ ) and at the west end of the site in 
Test Unit 5 (18 per m3)(Figure 15).

Vertically. Debitagedensities across the site range between 4.5 to 9.5 flakes per $0.1 \mathrm{~m} 3$ for the upper 8 levels. and levels 1 and 12. Levels9, 10 , and 13 indicate a low density of flakes, ranging from 1.0 to 3.3 flakes per $0.1 \mathrm{~m} 3$.

Chert and quartzite materials were present across the site in roughly equal proportions, and there does not appear to be any localized use of any one particularmaterialtype. There is a decrease in chert and quartzite flake densities at the north and west ends of the site, in the vicinity of TestUnits 3 and 5. Test Units 1 and 2 , located at the southemmargin of thesite, contain much higherdensities of these materials. Petrified wood densities are low, but consistent across the site. Cultural use of FeMg is also low. but consistent. However, some of these pieces are questionableas cultural debitage.
Vertically, quartzite materialsare evenly distributed, typically ranging between 2 to 4 flakes per $0.1 \mathrm{~m}$ 'in the upper 8 levels. Density decreases to about 0.5 flakes per $0.1 \mathrm{~m} 3$ in level 10 , but then increases dramaticallyin level 12 to 8 flakes per $0.1 \mathrm{~m} 3$ (Figure 16).

The amount of flake cortex is also in roughly equal portions across the site. Tertiary flakes are the most abundant, followed by secondary and primary. Vertically, primary flakes are consistent throughout the profile, in low densities. Secondary flakes range vertically in density from about 0.5 to 2.5 flakes per $0.1 \mathrm{~m} 3$ throughout the upper 11 levels. Finally, tertiary flake density ranges from approximate 4 to 8 flakes per $0.1 \mathrm{~m} 3$ in levels 1-8, and 11-12. Density is between 1 and 2 flakes per $0.1 \mathrm{~m} 3$ for levels 9 and 10.

Flake type distributions across the site are fairly

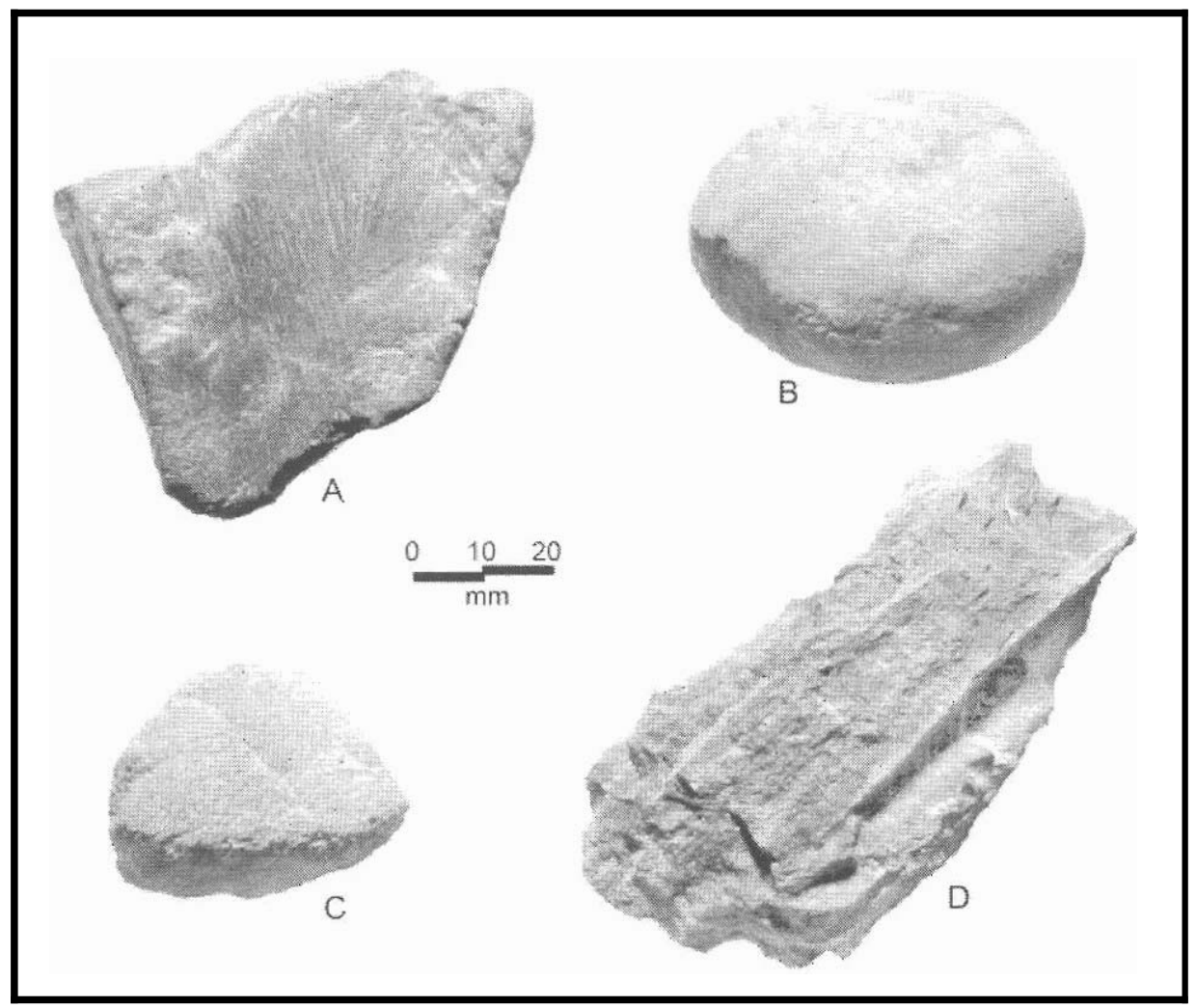

Figure 13. Groundstone and edge-modified tools from 41UR36: (a) hematite stone, TU 4, LV 9; (b) abrader stone, TU 3, LV 9; (c) incised rock, TU 4, LV 9; (d) edge-modified flake, TU 3, LV 4. 
uniform for Test Units 1, 3, 4,and 5, with roughly equal proportions of types. However, analysis of spatial trends indicates that Test Unit 2 contained a noticeably larger number of biface thinning flakes and softhammerpercussionflakes, relative to shatter and hardhammer flakes. Vertically,for the whole site, there is a gradual decrease in the density for all flake types with increasing depth, from about 2 to 0.5 flakes per $0.1 \mathrm{~m} 3$. The relative proportions of platform types are consistent across the site. Vertically, density for each type gradually decreases with increasing depth.

\section{DISCUSSION}

The twelve ceramic sherds recovered from the site are comprised of body sherds and one rim sherd. Although brushing and incising are evident on some of the sherds, the pieces were too fragmentary to assign a type. However, these fragments fitcomfortably within the descriptive range of ceramics identified at this site during the Big Sandy Project, which consisted mainly of brushed, incised, and punctated ceramic wares associated with the Late Caddoan Period (Perttula et al. 1986:278). As such, the Caddoan component of this site likely dates to around A.D. 1450, and may be contemporaneous with the Whelan Phase in the Cypress Creek Basin (see Perttula et al. 1986:278).

Overall, relativelyfew temporally or functionally diagnostic tools were recovered from the proposed area of project impacts. Except for three projectile points, only one other formal tool, a large axe-like biface, was recovered. The remainder of recovered tools consistsof a few expedient, modified natural stones and an expedientedge-modified/utilizedflake. Survey work preceding these investigations identified a scraper and nutting stone at the northeastend of the site, and investigations during the Big Sandy Project revealed a Bell dart point between 30 and $40 \mathrm{~cm}$ below surface east of the project area. No formal tools are reported elsewhere. The relatively low numbers of primary and secondary corticated flakes, and abundance of interior, softhammer, and biface thinning flakes, suggest an emphasis toward tool maintenance, retouch, and refinishing rather than the initial reductionstages of thetool making process. This would be consistent with the low number of tools and cores recovered.

The three identified featuresconsisted of only a few disarticulated rocks. No bone, shell, charred materials, or discolored sediments were observed in association with any of the features. Furthermore, none of the surrounding matrix could be distinguished from the feature matrix on sedimentologicor pedologic properties.

Several observations were made from an examination of the horizontaland vertical distributionof features, tools, and debitage. None of the tools were recovered in the upper $30 \mathrm{~cm}$; most were recovered from between 80 and $130 \mathrm{~cm}$. There is a corresponding decrease in debitagedensity from 80 to $100 \mathrm{~cm}$. Several of the tools were found in possible association with features. An incised pebble, hematite stone, and abraderstone were found near Feature 2 in Test Unit 4 beginning at $80 \mathrm{~cm}$ below surface. The edge-modified flake is possibly associated with Feature 3 in levels 4-5 in Test Unit 3 , and the Ellis-like dartpoint with Feature 1 in Test Unit 1 in levels 6-7.

Overall, the majority of recovered materials were identified at the south and east ends of the site within the project limits. Debitage densityalso increases from north to south and from west to east. Vertically, the highest debitage densitiesare in levels 1-8, and the lowest densities are recorded for levels 9 and 10. Most of the tools are located at levels with associated decreases in debitagedensity. 
Ceramics were found up to $50 \mathrm{~cm}$ below surface, although they were mainly concentrated in the upper $30 \mathrm{~cm}$. The majority of theceramics were located at the south and east sides of the site. Only two sherds were found at the northernmostend of the site. Similarly, previous investigationsduring the Big Sandy Project revealed ceramics concentrated in the upper 20 $\mathrm{cm}$, near the southeast end of theproject limits.

Vertically, across the site, there appears to be several zones of cultural materials. The uppermost zone $(0-30 \mathrm{~cm})$ contains Caddoceramics, without any Archaic diagnostics. Included in the zone were nine out of the 12 ceramics, one core, no features, and several debitage. The middle zone $(30-70 \mathrm{~cm})$ contains mixed deposits of Caddoan and Archaic materials, and includes two sherds, the Bell point identified during the Big Sandy Project, two features, one edge-modified flake, one nutting stone, one Ellis-like dart point, and a decrease in debitage density. From $70-80 \mathrm{~cm}$, there is a "dead zone"from which no tools were recovered. There is also a dramatic decrease in debitage density beginning in this zone. The lower zone $(80-130 \mathrm{~cm})$ contained one feature, six tools, including one Yarbrough-likedartpoint and a Gary dartpoint, and an increase in debitage density from $100-120 \mathrm{~cm}$. The upper boundary of this zone is capped by several clay lamellaethat were observed in profile. Although these lamellae might not be indicatorsof good site context and integrity, particularly if they are purely pedogenic in origin (Carole Mandryk, personal communication 2000), However, lamellae may serve as a useful marker horizon for locating discrete Middle Archaic Period materials if future excavations are planned at this site.

\section{CONCLUSIONS AND RECOMMENDATIONS}

The purpose of the fieldwork was to detennine if this portion of the site contained sufficient preserved features and artifacts, and to evaluate whether or not there were adequate temporal controls to make meaningful inferences about past land use.

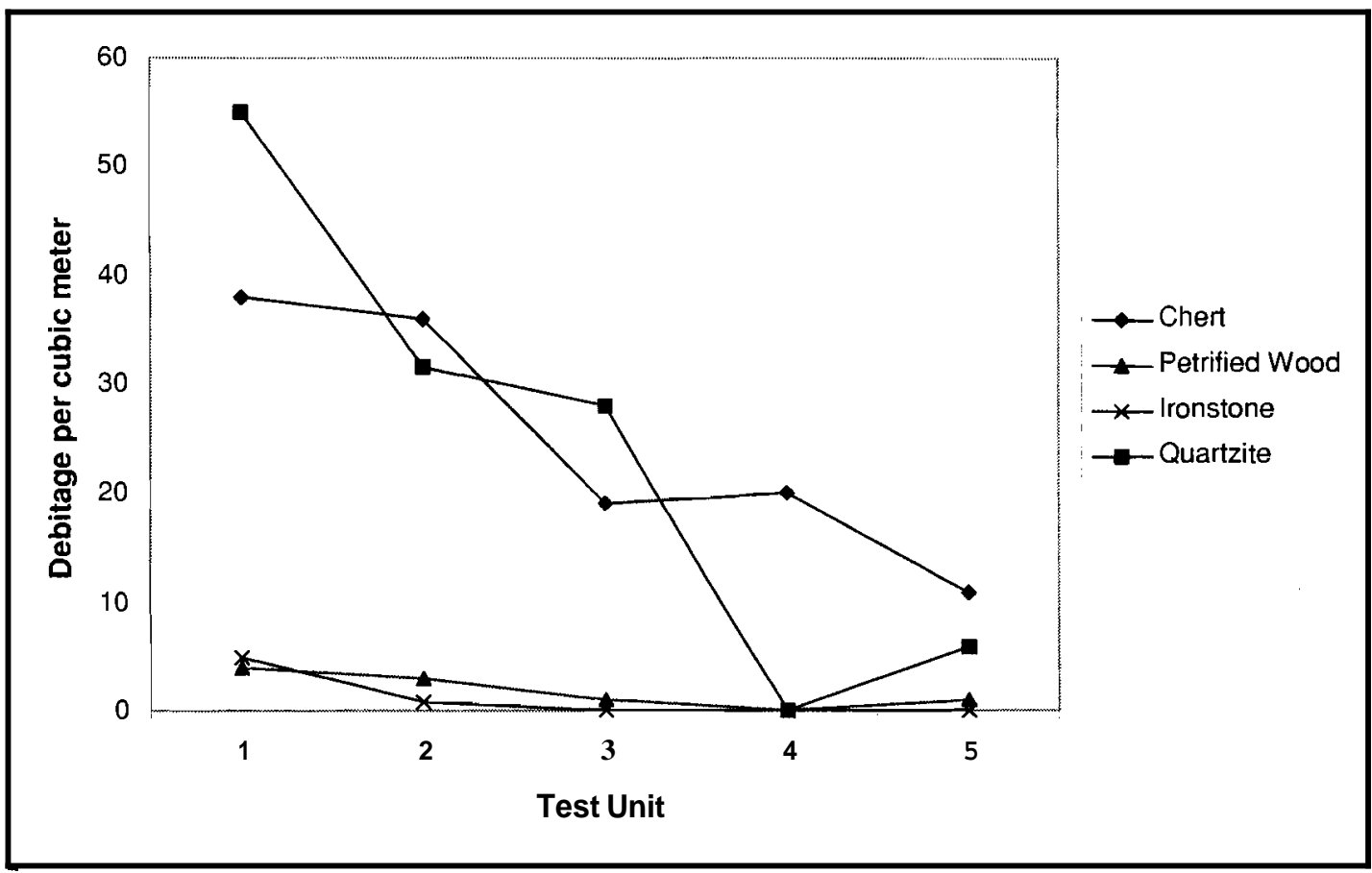

Figure 14. Debitage densities in test units at 41UR36. 


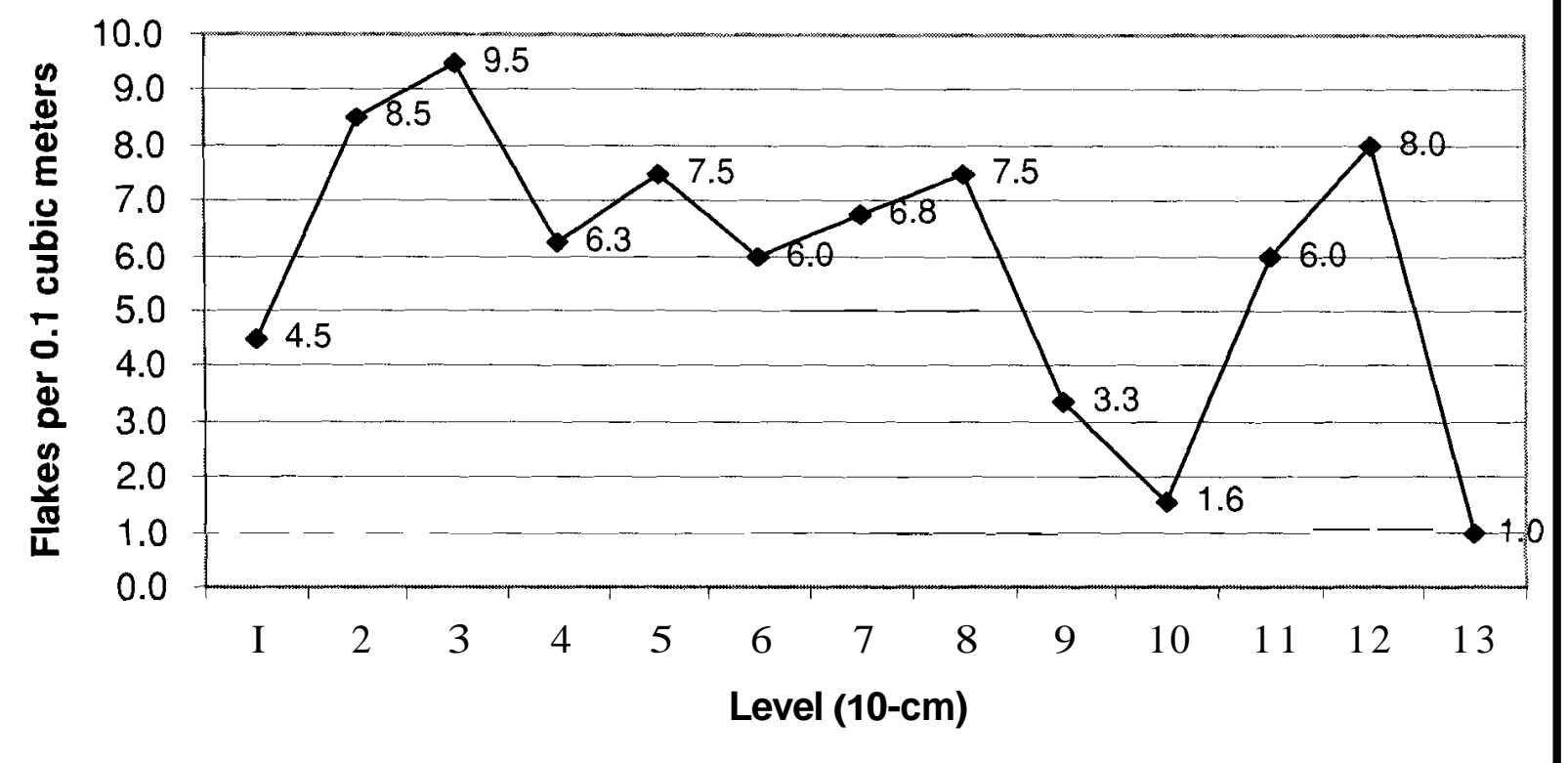

Figure 15. Site-wide debitage density by level.

Testing results indicate that archeological deposits at 41UR36 may be stratified. An isolated, discrete Archaicoccupation zone appears to be present below the range of mixed deposits. However, the portion of the site within the APE does not appear to offer much potential to contain sufficient information needed to address significant researchissues about land use, subsistence, technology, chronology, or site function. Artifact and feature densities were low. The three features were extremely small and disarticulated. Furthermore, feature matrices lacked shell, bone, or charred materials of any kind. Finally, features and presumed associated artifacts are only tenuously linked, and without sufficienttemporal controls (i.e., datable remains for radiometric dating), stronger relationships cannot be firmly established. Since the context of this site is not conducive to the preservation of faunal and botanical remains, chronometricdata may be difficultto obtain for older components. Field observationsalso indicate that the site is not conducive to the preservation of features. The burned sandstone and FeMg nodules that were found isolated throughout most levels are probably the remnants of former features, and have been displaced vertically over time through various site formation processes.

Based on field observations and the nature and distributionof the artifact assemblage, the upper deposits appear to have been impacted, reworked, and mixed to a point beyond our ability to gain useful information about the native inhabitants of thisregion. The small quantity of recovered materials, feature remnants, and the largely non-diagnostic character of the assemblage limit the amount of information that can be derived. 
Vertically discrete, low artifactdensities would result in a different conclusion, since this would represent littleoverprinting of components. However, this site does not appear to be in an aggradating environment. The apparent separation of materials is likely a case of artifacts migrating down through an upland sandy profile by bioturbation processes. Ants and ant holes were observed even at 1.4 meters below surface. given the mixing that has occurred in portions of both components, drawing disticntions between them would certainly be arbitrary. Thus, the Archaic package may not be as discrete as previously thought.

Based on these investigations, the portion of site 41UR36 within the proposed widening will not likely yield information that would contribute to the NRHP eligibility of the site. There- fore, the proposed project should have no effect on archeological historic properties and no further archeological work is recommended for the proposed project.

Althoughimportantinformation potential is lacking within the immediate boundaries of the bridge widening project, other areas of the site outside the project area may offer greater potential to addressquestions about Archaic settlement, subsistence, and technology in the upper Glade Creek drainage. The majority of the site likely extends east of theproject limits. Thus, future work in this part of the site may yield comparativeinformationthat would be useful for understanding land-use patterns along Glade Creek, and how these patterns relate to utilization of other major and minor drainages within the Sabine Basin (Gadus 1999; Perttula et al. 1986). 



\section{REFERENCESCITED}

Ahler, S.A., and A.A. Swenson

1985 Test Excavations at the Big Hidatsa Village(32ME12), Knife River Indian Villages National Historic Site. Contribution No. 218. Department of A nthropology, University of North Dakota, Grand Forks.

Blair, W.F.

1950 The Biotic Provinces of Texas. The Texas Journal of Science 2(1):93-116.

Fenneman,N.M.

1931 Physiography of the Western United States. McGraw-Hill, New York.

Fields, R.C., S.A. Tomka, and T.K. Perttula

1993 Hunter-GathererMobility in Northeast Texas. In Archeologyin the Eastern Planning Region, Texas: A Planning Document, edited by N.A. Kenmotsu and T.K. Perttula, pp. 6996. Cultural Resources Management Report No. 3. Department of A ntiquitiesProtection,Texas Historical Commission, Austin.

Gadus, E.F.

1999 Archeological Survey and Impact Evaluation at FM 1002 and Glade Creek, Upshur County, Texas. Letter Report No. 433. Prewitt and Associates, Inc., Austin.

Gould, F.W.

1975 Texas Plants: A Checklist and Ecological Summary. The Texas A\&M University System, Texas Agricultural ExperimentStation, College Station.

Perttula,T.K.

1992 The Caddo Nation: Archaeologicaland Ethnohistorical Perspectives. University of Texas Press, Austin.

1993a The Developmentof agriculture in Northeast Texas Before A.D. 1600. In Archeologyin the Eastern Planning Region, Texas: A Planning Document. Cultural Resources Manage ment Report No. 3., edited by N.A. Kenmotsu and T.K. Perttula, pp. 124-146. Department of AntiquitiesProtection, Texas Historical Commission,Austin.

1993b Effects of European Contact on Native and Immigrant Indians in Northeast Texas. In Archeology in the Eastern Planning Region, Texas: A Planning Document. Cultural Resources Management Report No. 3., edited by N.A. Kenmotsu and T.K. Perttula, pp. 147187. Department of A ntiquitiesProtection, Texas Historical Commission, Austin.

1999 The Hurricane Hill Site (41HP106): The Archaeology of a Late Archaic/Early Ceramic and Early Middle Caddoan Settlement in Northeast Texas. U.S. Army Corp of Engineers, Forth Worth District, Special PublicationNo. 4, Friends of NortheastTexas Archaeology. 
Perttula, T.K., and J.E. Bmseth

1998 The Native History of the Caddo and Their Place in Southeastern Archeology and Ethnohistory. Studies in Archeology 30. Texas Archeological Research Laboratory, The University of Texas at Austin.

Perttula, T.K., and N.A. Kenmotsu

1993 Introduction. In Archeology in the Eastern Planning Region, Texas: A Planning Document. Cultural Resources Management Report No. 3., edited by N.A. Kenmotsu and T.K. Perttula, pp. 35-47. Department of A ntiquities Protection, Texas Historical Commission, Austin.

Perttula, T.K., R.C. Fields, J.E. Corbin, and N.A. Kenmotsu

1993 The Emergence of Sedentism in Northeast Texas, ca. 500 B.C. to A.D. 1000. In Archeology in the Eastern Planning Region, Texas: A Planning Document. Cultural Resources Management Report No. 3, edited by N.A. Kenmotsu and T.K. Perttula, pp. 97120. Department of A ntiquitiesProtection, Texas Historical Commission, Austin.

Perttula, T.K., B.D. Skiles, M.B. Collins, and F. Valdez Jr.

1986 This Everlasting Sandbed: Cultural Resources Investigations at the Texas Big Sandy Project, Wood and Upshur Counties, Texas. Report of Investigations No. 52. Prewittand Associates, Inc., Austin.

Roberts, K.

1983 Soil Survey of Upshur and Gregg Counties, Texas. U.S. Department of Agriculture, Soil Conservation Service, in cooperation with TexasAgriculturalExperiment Station.

Story, D.A.

1990 Cultural History of the Native Americans. In The Archeology and Bioarcheology of the Gulf Coastal Plain: Volume I, by D.A. Story, J.A. Guy, B.A. Burnett, M.D. Freeman, J.C. Rose, D.G. Steele, B.W. Olive, and K.J. Reinhard, pp. 163-366. Research Series No. 38. A rkansas A rcheologicalSurvey, Fayetteville.

Thurmond, P. J.

1990 Archeology of the Cypress Creek Drainage Basin, Northeastern Texas and North western Louisiana. Studies in Archeology 5, Texas Archeological Research Laboratory, The University of Texas at Austin.

Turner, E.S., and T.R. Hester

1993 A Field Guide to Stone Artifacts of Texas Indians. Second edition. Texas Monthly Field Guide Series. Gulf Publishing Company, Houston, Texas. 




\section{APPENDIX:}

TEST UNIT PROFILES AND BACKHOE TRENCH DESCRIPTIONS 

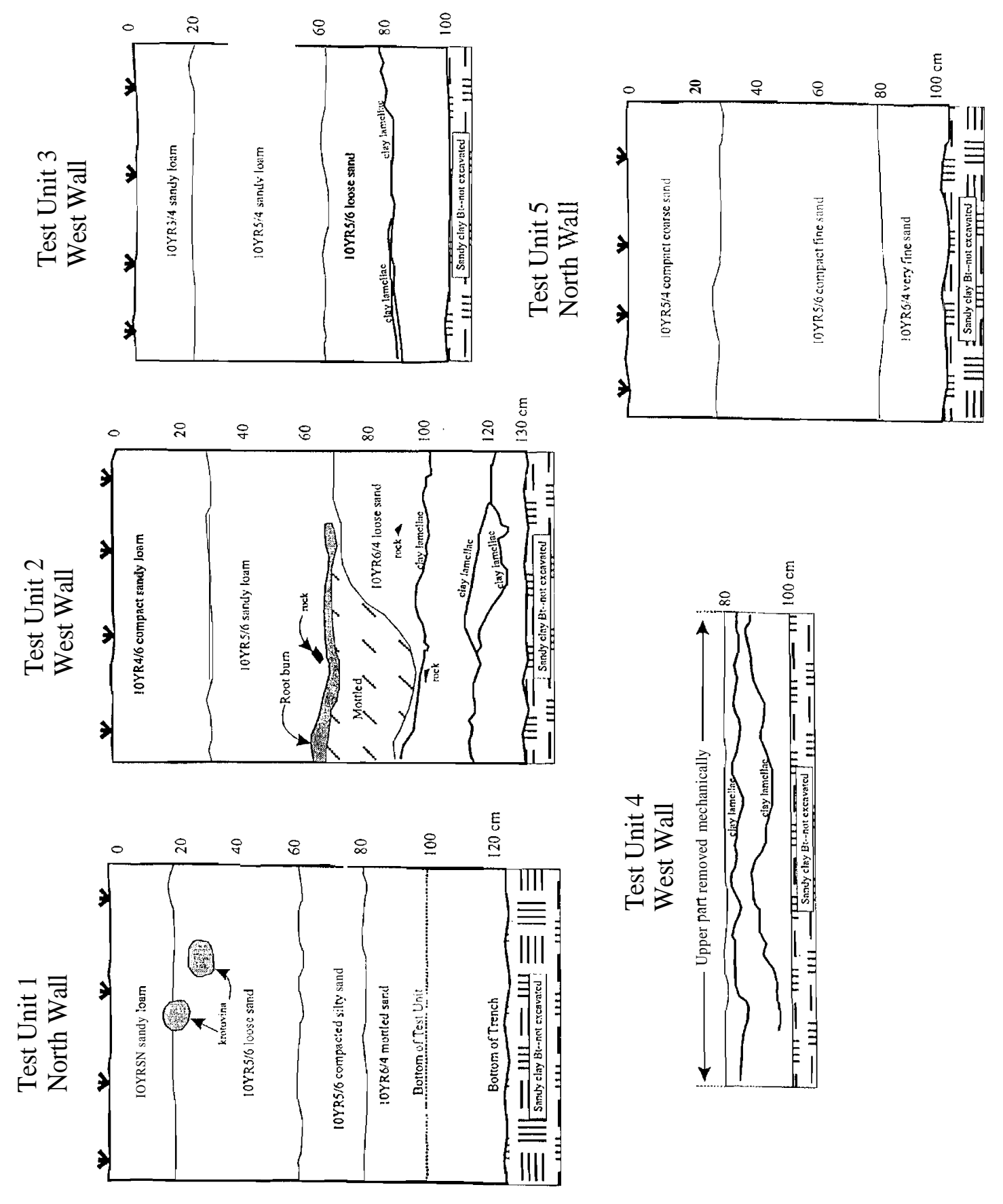


\section{Backhoe Trench 1b}

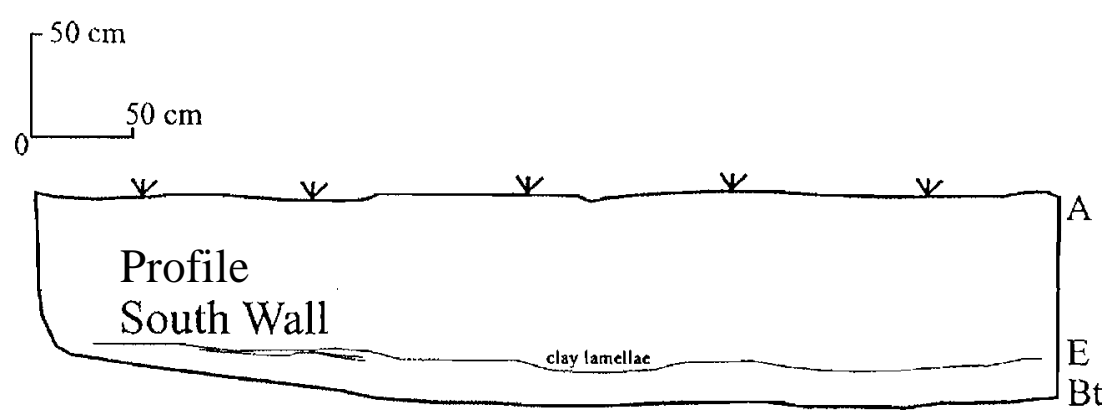

\section{Plan view}

Test Unit 1

\begin{tabular}{|c|c|c|}
\hline Zone & Depth (cm) & Description \\
\hline 1 & $0-20$ & Dark yellowish brown (10Y R3/4) sandy loam. \\
\hline 2 & $20-60$ & Light yellowish brown (10Y R 4/6) loose sand. \\
\hline 3 & $60-90$ & $\begin{array}{l}\text { Compact yellowish brown (10Y R } 5 / 6) \text { mottle sand. Clay and silt } \\
\text { content increase in this zone. Krotovinas, root casts, and insect casts } \\
\text { are common throughout zone. }\end{array}$ \\
\hline 4 & $90-100$ & $\begin{array}{l}\text { Light yellowish brown (10Y R } 6 / 4) \text { loose sand. B-horizon. Clay } \\
\text { lamellae are present at about } 80 \mathrm{~cm} \text { below surface. Some mottles are } \\
\text { present. }\end{array}$ \\
\hline 5 & $100+$ & Sterile claypan Bt-horizon. \\
\hline
\end{tabular}




\section{B ackhoeTrench $2 b$}

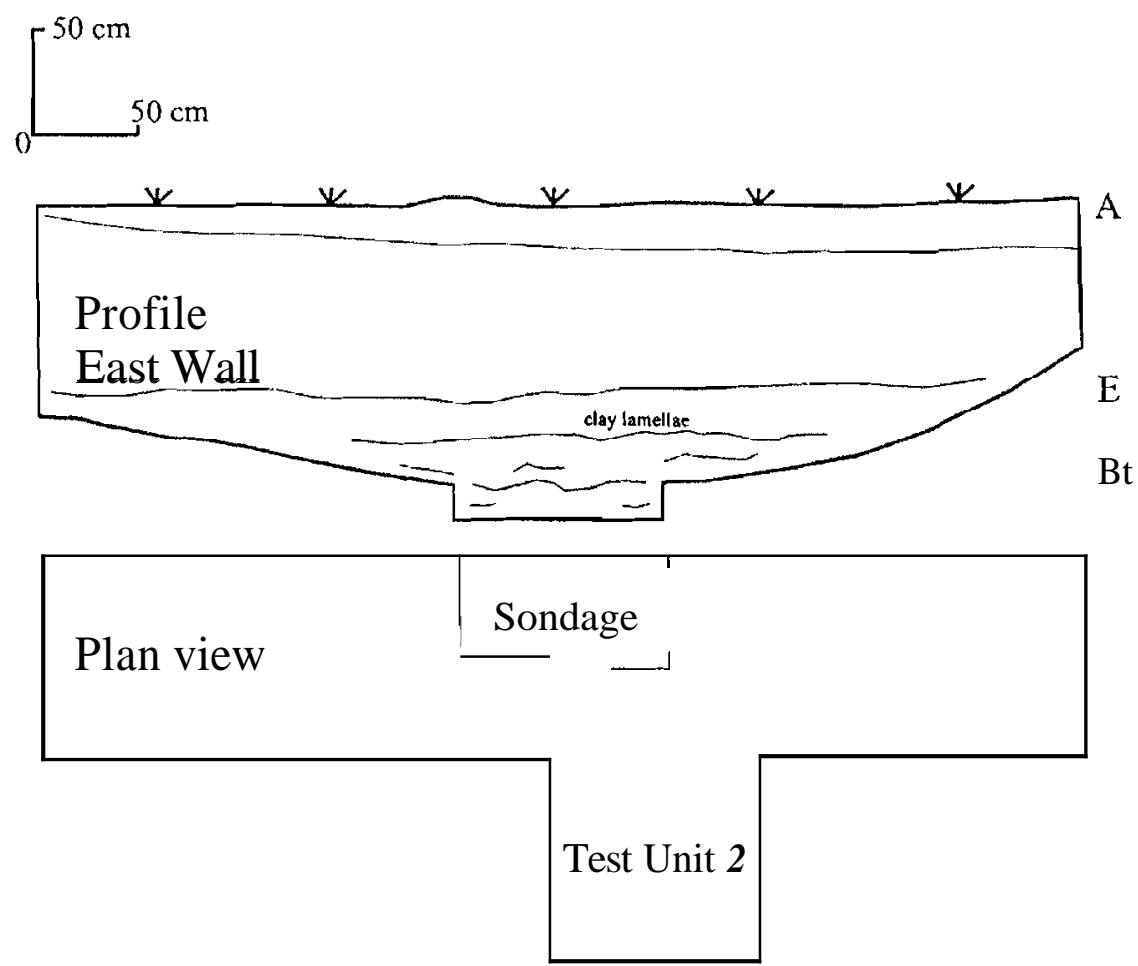

\begin{tabular}{|c|c|c|}
\hline Zone & Depth (cm) & Description \\
\hline 1 & $0-30$ & Dark yellowish brown (10Y R 3/6) sandy loam. Ap-horizon. \\
\hline 2 & $30-70$ & Light yellowish brown (10Y R 4/4) loose sand. \\
\hline 3 & $70-130$ & $\begin{array}{l}\text { Yellowish brown (10Y R 5/6) loose sand. E-horizon. Clay lamellae are } \\
\text { present at about } 100-120 \mathrm{~cm} \text { below surface. }\end{array}$ \\
\hline 4 & $130+$ & Sterile claypan Bt-horizon. \\
\hline
\end{tabular}




\section{Backhoe Trench $3 \mathrm{~b}$}
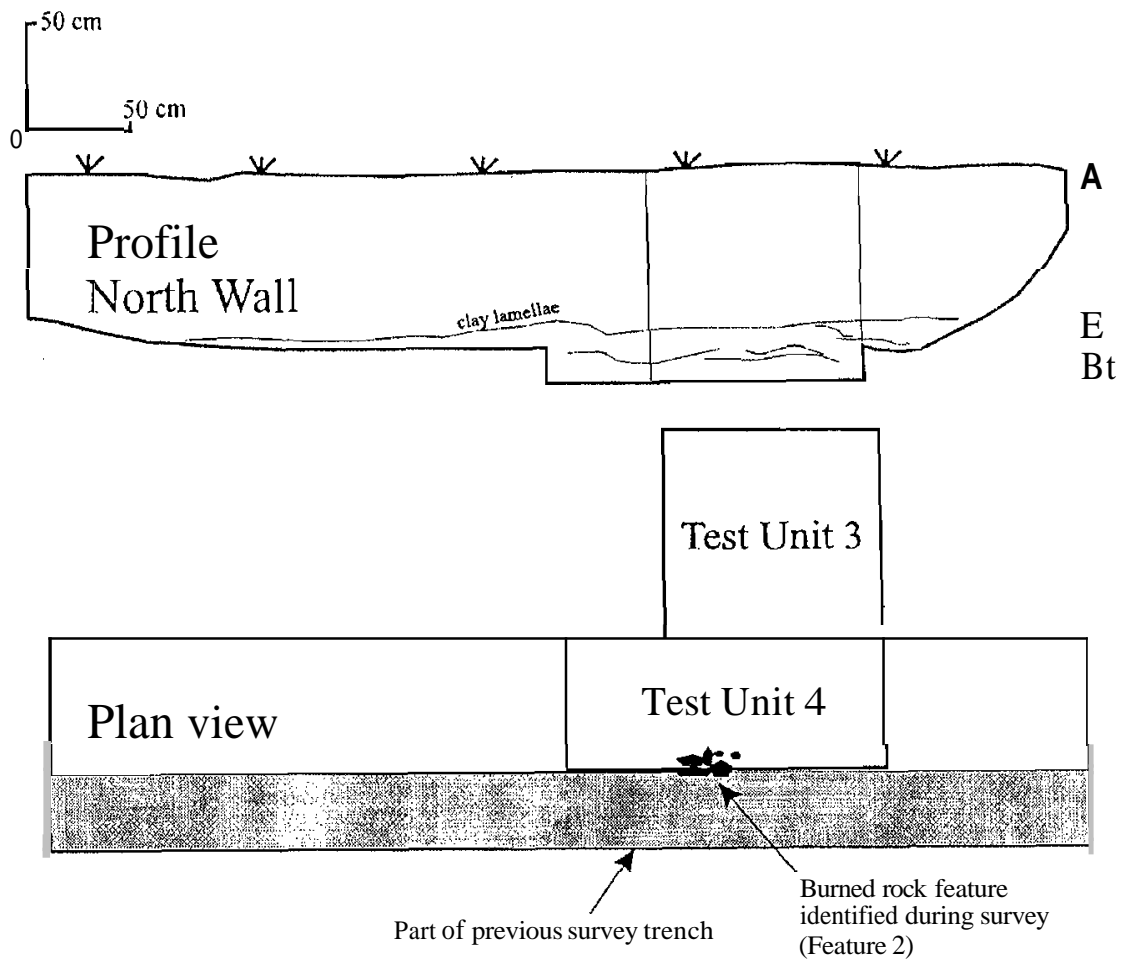

\begin{tabular}{|c|c|c|}
\hline Zone & Depth $(\mathrm{cm})$ & Description \\
\hline 1 & $0-20$ & Compacted dark yellowish brown (10YR3/4) sandy loam. \\
\hline 2 & $20-60$ & Light yellowish brown (10Y R5/4) sandy loam. \\
\hline 3 & $60-100$ & $\begin{array}{l}\text { Light yellowish brown (10YR5/6) Ioose sand grading into compact } \\
\text { yellowish brown mottle sand. E-horizon. Clay and silt content } \\
\text { increase in this zone. Clay lamellae are present at about } 70-100 \mathrm{~cm} \\
\text { below surface. }\end{array}$ \\
\hline 4 & ca. $100+$ & Sterile claypan Bt-horizon. \\
\hline
\end{tabular}

